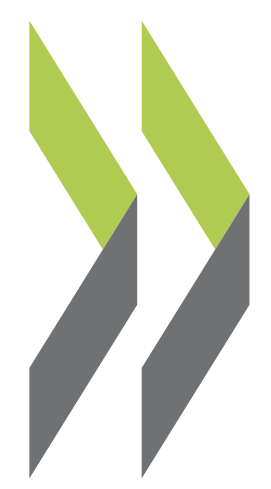

OECD Economics Department Working Papers No. 1625

The effect of energy prices and environmental policy stringency on manufacturing employment in OECD

countries: Sector- and firmlevel evidence

Antoine Dechezleprêtre, Daniel Nachtigall, Balazs Stadler 


\section{ECONOMICS DEPARTMENT}

\section{THE EFFECT OF ENERGY PRICES AND ENVIRONMENTAL POLICY STRINGENCY ON MANUFACTURING EMPLOYMENT IN OECD COUNTRIES: SECTOR-AND FIRM-LEVEL EVIDENCE}

\section{ECONOMICS DEPARTMENT WORKING PAPERS No. 1625}

By Antoine Dechezleprêtre, Daniel Nachtigall and Balazs Stadler

OECD Working Papers should not be reported as representing the official views of the OECD or its member countries. The opinions expressed and arguments employed are those of the author(s).

Authorised for publication by Alain De Serres, Deputy Director, Policy Studies Branch, Economics Department.

Antoine Dechezleprêtre: Antoine.DECHEZLEPRETRE@,oecd.org

Daniel Nachtigall: Daniel.NACHTIGALL@,oecd.org

Balazs Stadler: Balazs.STADLER@oecd.org

JT03466167 
OECD Working Papers should not be reported as representing the official views of the OECD or of its member countries. The opinions expressed and arguments employed are those of the author(s).

Working Papers describe preliminary results or research in progress by the author(s) and are published to stimulate discussion on a broad range of issues on which the OECD works.

Comments on Working Papers are welcomed, and may be sent to OECD Economics Department, 2 rue André Pascal, 75775 Paris Cedex 16, France, or by e-mail to eco.contact@oecd.org.

All Economics Department Working Papers are available at www.oecd.org/eco/workingpapers

This document and any map included herein are without prejudice to the status of or sovereignty over any territory, to the delimitation of international frontiers and boundaries and to the name of any territory, city or area.

\section{(c) OECD (2020)}

You can copy, download or print OECD content for your own use, and you can include excerpts from OECD publications, databases and multimedia products in your own documents, presentations, blogs, websites and teaching materials, provided that suitable acknowledgment of OECD as source and copyright owner is given. requests for commercial use and translation rights should be submitted to rights@oecd.org 


\section{Abstract / Résumé \\ The effect of energy prices and environmental policy stringency on manufacturing employment in OECD countries: Sector- and firm-level evidence}

This study empirically assesses the impact of energy prices and environmental policy stringency (EPS) on manufacturing employment in OECD countries over the period 20002014. At the sector level, increases in energy prices and in EPS have a negative and statistically significant impact on total employment in the manufacturing sector. Energyintensive sectors are most affected, while the impact is not statistically significant for less energy-intensive sectors. Even in highly energy-intensive sectors, however, the size of the effect is relatively small. Moreover, higher energy prices increase the probability of firm exit, but they have a statistically significant and small positive effect on the employment level of surviving firms. Accelerated firm exit allows surviving firms to expand, boosting firm-level employment. Therefore, the analysis demonstrates that there exist transition costs in the short run to imposing stricter environmental policies, as some workers are forced to move away from affected firms and sectors, even if many of these job losses are unlikely to be permanent as laid-off workers may ultimately find other jobs, notably in the services sector.

JEL classification codes: Q52, Q54, Q58

Keywords: Environmental policies, energy prices, employment, firm performance, competitiveness

$* * * * *$

\section{L'effet des prix de l'énergie et de la sévérité des politiques environnementales sur l'emploi manufacturier dans les pays de l'OCDE : Analyse au niveau des secteurs et des entreprises}

Cette étude présente une analyse empirique de l'effet des prix de l'énergie et de la sévérité des politiques environnementales sur l'emploi manufacturier dans les pays de l'OCDE sur la période 2000-2014. Au niveau sectoriel, une augmentation des prix de l'énergie et de la sévérité des politiques environnementales a un effet négatif et statistiquement significatif sur l'emploi manufacturier total. Les secteurs les plus intensifs en énergie sont les plus affectés, tandis que l'effet n'est pas statistiquement significatif dans les secteurs moins intensifs en énergie. Cependant, même dans les secteurs intensifs en énergie, la taille de l'effet est relativement faible. De plus, l'augmentation des prix de l'énergie augmente la probabilité de faire faillite mais a un effet positif et statistiquement significatif sur l'emploi des firmes restant sur le marché. La sortie du marché de certaines firmes se traduit donc par une augmentation de m'emploi chez les firmes qui survivent. L'analyse démontre donc qu'il existe au minimum des coûts de transition sur le court terme à imposer des politiques environnementales plus sévères, puisque certains travailleurs sont conduits à quitter leur emploi, même si ces pertes d'emploi sont temporaires et que les travailleurs retrouvent finalement un emploi dans un autre secteur (en particulier les services, qui ne sont pas analysés ici).

Classification JEL : Q52, Q54, Q58

Mots-clés : Politiques environmentales, prix de l'énergie, emploi, performance des entreprises, compétitivité 


\section{Table of Contents}

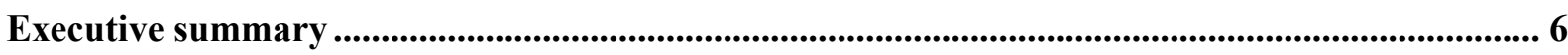

The effect of energy prices and environmental policy stringency on manufacturing employment in OECD countries: Sector- and firm-level evidence .................................................. 8

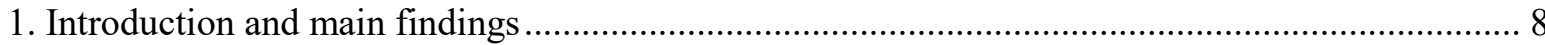

2. Environmental policies and firm employment: Theory and prior evidence …............................. 11

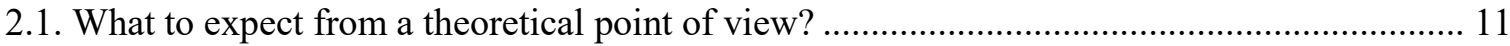

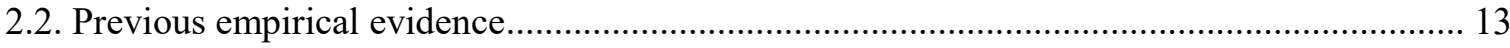

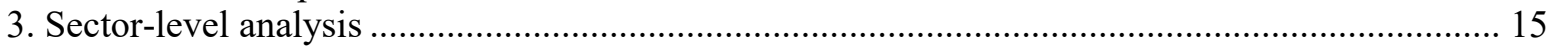

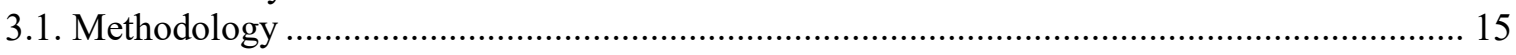

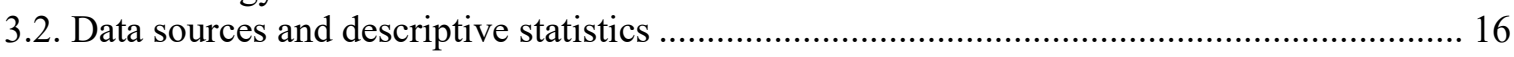

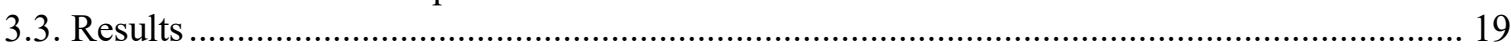

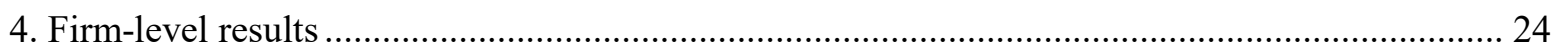

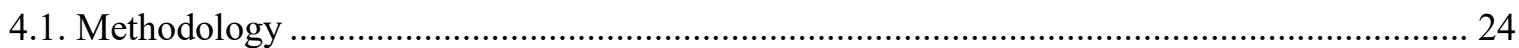

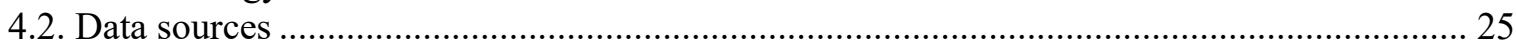

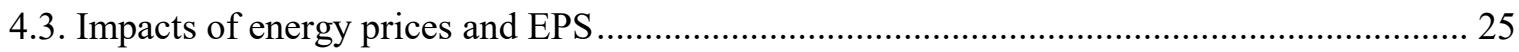

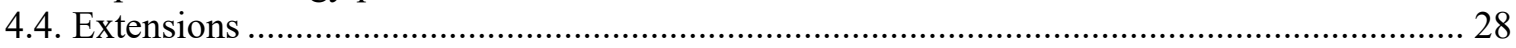

5. Impact of energy price and environmental policy stringency on entry and exit ............................ 31

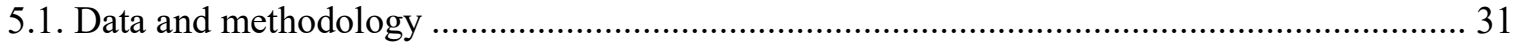

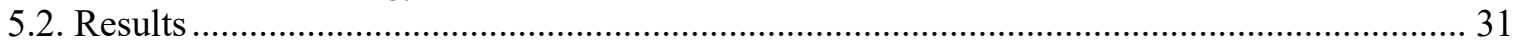

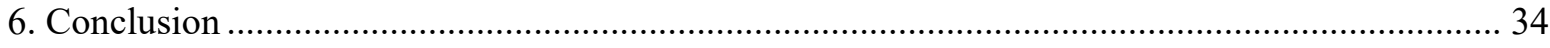

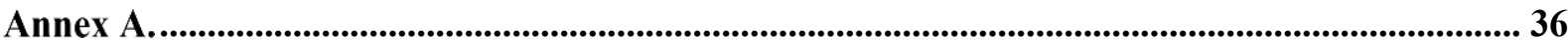

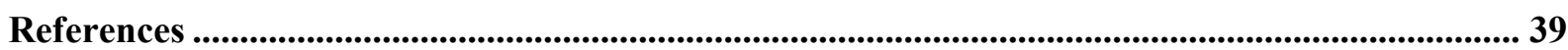

\section{Tables}

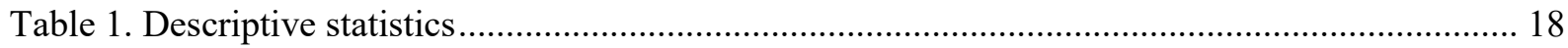

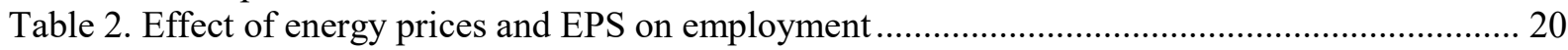

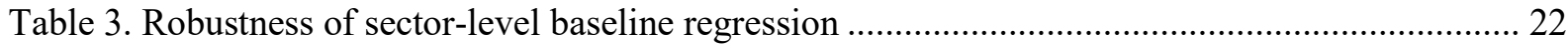

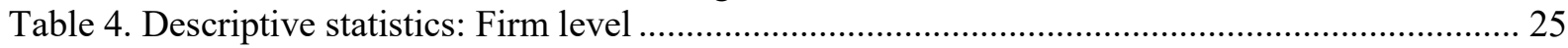

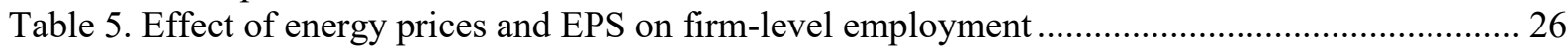

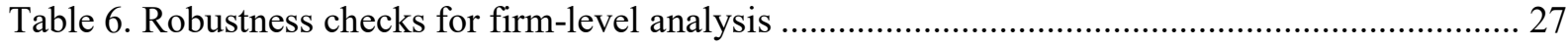

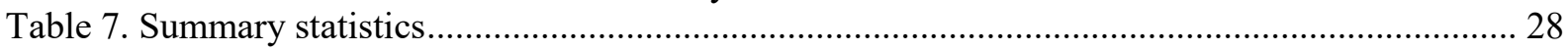

Table 8. Effect of energy prices and EPS depending on the number of employees ............................... 30

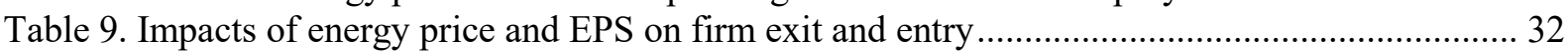

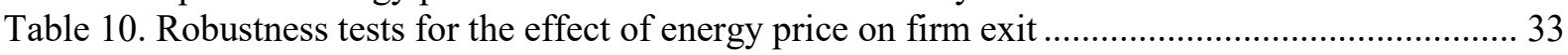

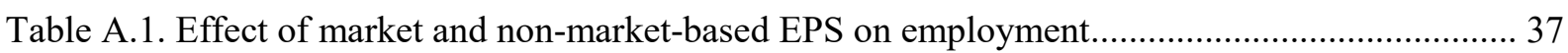

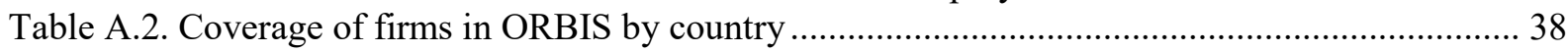

Table A.3. Effect of energy prices and EPS on gross output …….................................................. 38 


\section{Figures}

Figure 1. Employment and energy prices in the manufacturing sector, 2000-14 ............................... 9

Figure 2. Energy cost shares as percentage of gross output across manufacturing sectors ................... 12

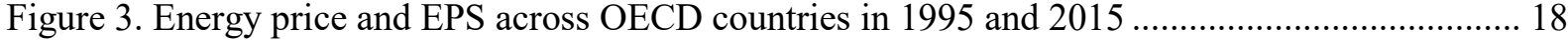

Figure 4. The employment effects of higher energy prices differ across sectors .................................. 23

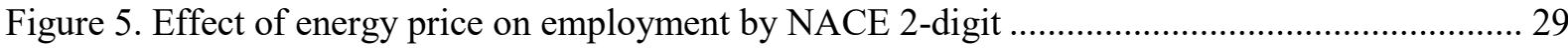

Figure 6. Heterogeneous effects in the most energy intensive sectors .............................................. 30

Figure A.1. Correlation between residuals from regressions of energy prices and EPS on country

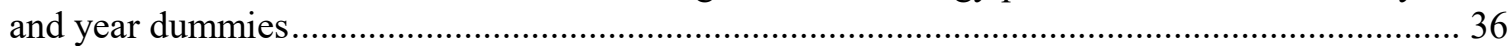

Figure A.2. Sector-level analysis: Effect of EPS on employment by sector ..................................... 36

Figure A.3. Firm-level analysis: Variation of energy prices .............................................................. 37

\section{Boxes}

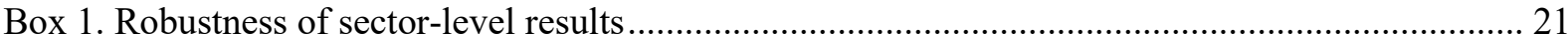

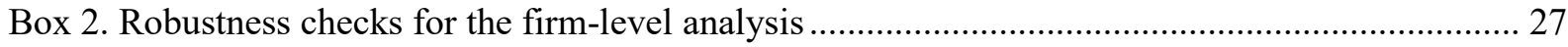

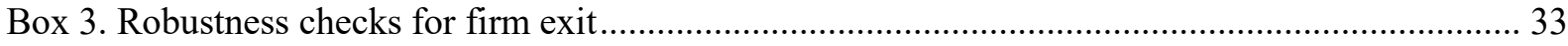




\section{Executive summary}

In a world where countries or regions implement environmental policies at different paces, there are concerns that differences in regulatory stringency could undermine the competitiveness of firms located in countries with stricter policies. Therefore, discussions about the appropriate stringency level of environmental regulations are often framed in terms of 'jobs versus the environment'.

This paper empirically assesses the impact that past changes in environmental policies have had on manufacturing employment in OECD countries over the period 2000-14. The analysis is carried out both at the sector and at the firm level and uses two complementary measures of environmental policy: energy prices and the OECD Environmental Policy Stringency (EPS) indicator. While there is a high cross-sectional correlation between the levels of energy prices and EPS, the correlation between the year-on-year variation of both variables is negligible.

The paper shows that, at the sector level, increases in energy prices and in the stringency of environmental policies have a negative and statistically significant impact on total employment in the manufacturing sector. The overall magnitude is small, however: a $10 \%$ increase in energy prices leads to a reduction of manufacturing employment by $0.7 \%$. To put things in perspective, job losses linked with increases in energy prices are estimated to be respectively $30 \%$ and $80 \%$ smaller than those due to automation and globalisation. Moreover, these job losses might be partially or completely offset by hires in nonmanufacturing sectors, which are not considered here.

Energy-intensive sectors (e.g. non-metallic minerals, iron and steel) are most affected, while the impact is not statistically significant for less energy-intensive sectors. Even in highly energy-intensive sectors, however, the size of the effect is relatively small: in iron and steel production - the most affected sector - a $10 \%$ increase in the price of energy reduces manufacturing employment by $1.9 \%$ in the short run.

Aggregate effects at the sector level may mask heterogeneity at the firm level, calling for a more granular analysis. At the micro level, the results show that higher energy prices have a statistically significant and small positive effect on the employment level of surviving firms. However, these average effects at the firm level again hide important heterogeneity. In particular sub-sectors (e.g. basic chemicals), even surviving firms suffer and lay off workers as a consequence of higher energy prices and stricter environmental policies.

The contrasting results of higher energy prices at the sector-level and firm-level can be reconciled when looking at business dynamics. The analysis on energy prices' effect on firm exit and entry shows that higher energy prices increase the probability of firm exit. Accelerated firm exit allows surviving firms to expand, boosting firm-level employment.

Contrary to higher energy prices, stricter environmental policies reduce employment of surviving firms. Looking at business dynamics, stricter environmental policies do not affect entry or exit of firms, suggesting that the negative effect on employment at the sector level mirrors the negative effect at the firm-level.

The analysis has two main limitations. First, to the extent that changes in energy prices or environmental regulations induce a rapid shift in demand (and thus employment) from strictly to less-strictly regulated sectors and regions, estimates of employment losses presented here would be biased upward. The extent of such general equilibrium effects are 
difficult to estimate, but the results should be understood as an upper-bound of the true effect of higher energy prices and stricter environmental policies. Second, the results are only valid in the short run. In the longer run, there might be no net effect on job losses as workers move from contracting or exiting firms to other firms or other sectors (in particular, the analysis focuses on the manufacturing sector, but affected workers might find jobs in the services sector).

However, the analysis clearly demonstrates that there exist transition costs in the short run to imposing stricter environmental policies, as some workers are forced to move away from affected firms and sectors, even if many of these job losses are unlikely to be permanent as laid-off workers may ultimately find other jobs. Because these reallocation effects have redistributive implications and generate costs for laid-off workers, these results call for complementary labour market policies that minimize those costs on affected workers and ease between-firms adjustments in employment. Moreover, since these transition costs are typically highly localised in regions specialised in polluting activities, they can also translate into potentially significant regional effects and thus political costs. Future work could focus on this geographical aspect of the green transition and take into account the political economy dimension to help design socially-acceptable environmental policies. 


\title{
The effect of energy prices and environmental policy stringency on manufacturing employment in OECD countries: Sector- and firm-level evidence
}

\author{
By Antoine Dechezleprêtre, Daniel Nachtigall and Balazs Stadler ${ }^{1}$
}

\section{Introduction and main findings}

1. Much of the environmental policy to date - and particularly climate policy - is asymmetric in nature. Some countries or integrated economic areas have imposed more stringent environmental policy measures than others. This raises the concern that such policies could undermine the "competitiveness" of firms located in countries with more stringent policies. Therefore, discussions about the appropriate stringency level of environmental regulations are often framed in terms of 'jobs versus the environment' (Morgenstern, Pizer and Shih, 2002 ${ }_{[1]}$ ), particularly in countries where falling employment in the manufacturing sector has been an important political issue.

2. A casual look at the recent evolution of manufacturing employment and energy prices (which are partly influenced by policies aimed at curbing carbon emissions, such as fuel taxes or emissions trading systems ${ }^{2}$ ) across OECD countries between 2000 and 2014 reveals a clear negative correlation between the two variables (Figure 1).

1. Antoine Dechezleprêtre is a member of the OECD's Economics Department and Environment Directorate. Balazs Stadler is a member of the OECD's Economics Department. Daniel Nachtigall is a member of the OECD's Environment Directorate. The authors would like to thank Shardul Agrawala, Damien Dussaux, Peter Hoeller, Tomasz Kozluk, Luiz de Mello, Valentine Millot, Giuseppe Nicoletti, Alain de Serres, Walid Oueslati, and members of the Working Party 1 of the OECD Economic Policy Committee and of the Working Party on Integrating Environmental and Economic Policies of the Environment Policy Committee for useful comments and suggestions. This document has been produced with the financial assistance of the European Union. The views expressed herein do not necessarily reflect the official opinion of the European Union.

2. For example, in Europe, the average industrial consumer pays 13\% of the gas price in taxes, and between $34-38 \%$ in taxes on electricity (European Commission, 2019). 
Figure 1. Employment and energy prices in the manufacturing sector, 2000-14

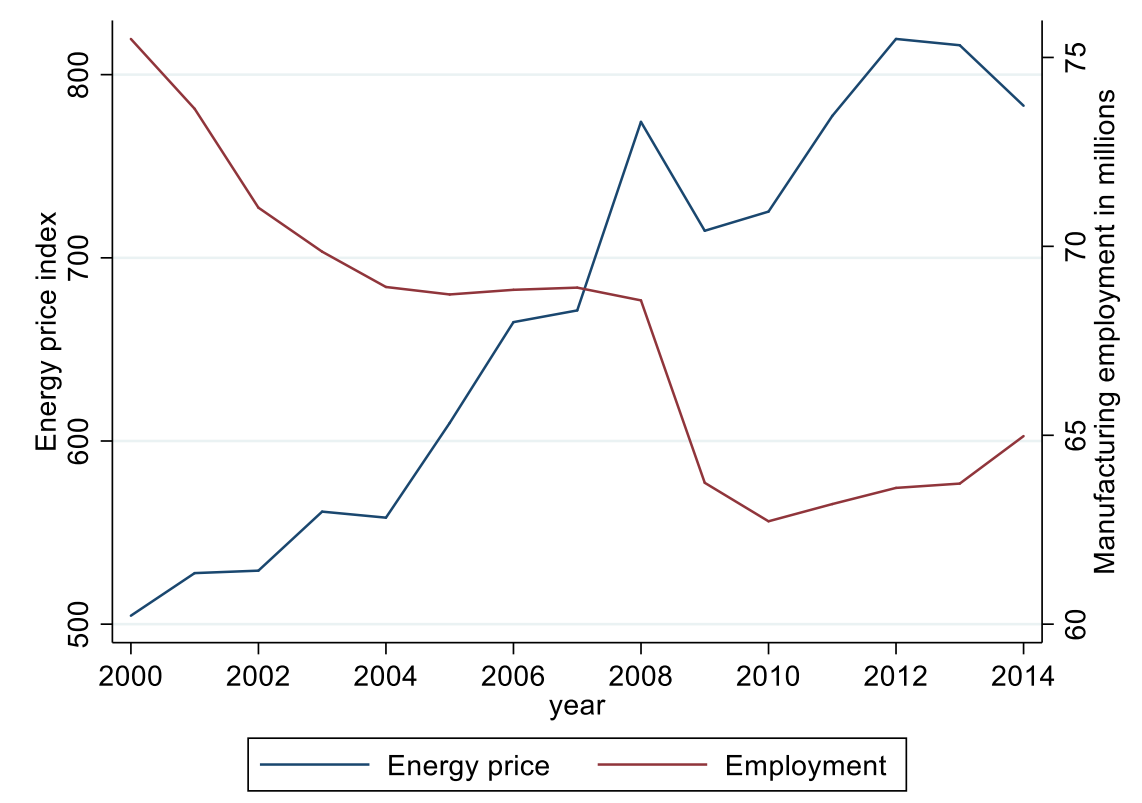

Source: Sato et al. (2019), WIOD (2016).

3. While energy prices have been rising almost continuously, total employment in the manufacturing sector fell during this period. This simple correlation has no causal interpretation but illustrates the fears that job losses might be the consequence of rising energy prices caused by more stringent environmental policies.

4. Employment is perhaps the most important concern for policy makers when enacting climate policies. However, evidence on the impact of environmental policies on this particular measure of economic performance is limited as existing studies typically focus on particular policies and regions (for example, the impact of the Clean Air Act in the United States). This paper empirically assesses the impact that past changes in environmental policies have had on manufacturing employment for all OECD countries and uses two complementary measures of environmental policy stringency: energy prices and the OECD Environmental Policy Stringency (EPS) indicator, allowing to draw more general conclusions than the existing literature on the topic. The EPS index covers a broad set of environmental policies, including market-based instruments, which assign an explicit price to environmental externalities (taxes on $\mathrm{CO}_{2}, \mathrm{SO}_{\mathrm{x}}, \mathrm{NO}_{\mathrm{x}}$, and diesel fuel; trading schemes for $\mathrm{CO}_{2}$, renewable energy certificates and energy efficiency certificates; feed-intariffs; and deposit-refund-schemes), and non-market instruments such as standards (emission limit values for $\mathrm{NO}_{\mathrm{X}}, \mathrm{SO}_{\mathrm{x}}$, and $\mathrm{PM}$, limits on sulphur content in diesel).

5. Climate change policies such as carbon taxes or cap-and-trade mechanisms primarily affect firms through raising energy prices (Aldy and Pizer, 2015 [2] ). Therefore, in the absence of explicit and comparable carbon prices in many countries, energy prices are informative about the likely effect of future policy interventions to reduce carbon emissions (Sato et al., 2015 $5_{[3]}$ ). While there are common factors that affect energy prices globally, such as oil and gas prices, there is considerable variation in energy prices across countries and sectors because of energy taxes or limited integration of energy markets due to 
transport costs or infrastructure bottlenecks. This variation can be exploited to determine the effect of energy prices on employment.

6. However, energy prices offer only a partial measure of environmental policy stringency. In particular, they do not capture non-market-based environmental policies such as command-and-control instruments (e.g. emission standards, air pollutant maximum concentration levels) which are not closely related to energy inputs. For this reason, the OECD's EPS index is used (Botta and Koźluk, 2014[4] ) as a complement to energy prices.

7. The paper investigates the impacts of environmental policy on employment both at the sector and at the firm level across OECD countries over the period 2000 to 2014. The analysis at the country-sector level has the advantage of allowing for within-sector labour reallocation across firms. Next, the paper explores three different channels for the sectorlevel results: the impact on entry and exit (based on data on the number of new and exiting firms) as well as the impact on surviving firms. The firm-level analysis is based on half a million OECD-based companies. The large dataset allows exploring heterogeneities of the impact of environmental policies and energy prices across narrowly-defined sectors and firm types.

8. The main findings are the following:

- First, at the sector level, increases in energy prices and in the stringency of environmental policies have a small but negative and statistically significant impact on total employment. As can be expected, the most energy-intensive sectors (e.g. non-metallic minerals, iron and steel) are affected the most, while the impact is not statistically significant for less energy-intensive sectors. Even in highly energy-intensive sectors, however, the size of the effects is relatively small: in iron and steel production - the most affected sector - a $10 \%$ increase in the price of energy reduces firm employment by $1.9 \%$ in the short run. While there is limited evidence on reallocation of labour within the manufacturing sector, affected workers may find jobs in other sectors, including services.

- At the firm level, however, the results show that higher energy prices have a statistically significant and small positive effect on the employment level of surviving firms. A $10 \%$ increase in energy prices would increase employment of the average surviving firm by $0.66 \%$.

- These average effects at the firm level again hide important heterogeneity. In particular sub-sectors (e.g. basic chemicals), even surviving firms suffer and lay off workers as a consequence of higher energy prices and stricter environmental policies.

- The opposing effects of higher energy prices at the sector-level and firm-level can be reconciled when looking at business dynamics. The analysis on energy price's effect on firm exit and entry shows that higher energy prices increase the probability of firm exit. Accelerated firm exit allows surviving firms to expand, boosting firmlevel employment. Indeed, we find evidence that surviving firms increase their turnover in response to higher energy prices: a 10\% increase in energy prices leads to an increase of gross output of $0.64 \%$.

- Contrary to higher energy prices, stricter environmental policies reduce employment of surviving firms in line with the sector-level analysis. Looking at business dynamics, stricter environmental policies do not affect entry or exit of 
firms, suggesting that the negative effect of stricter environmental policies on firm employment carries over to the sector-level.

9. Methodologically, the study uses a reduced-form empirical approach where the identification of the effect comes from comparing sectors and firms affected by changes in energy prices and in environmental policy stringency of varying magnitude. While this approach allows for a credible identification of the short-term effects of these phenomena on "treated" entities, it suffers from at least two well-known weaknesses. First, the model only captures short-term impacts and is not well suited to account for longer-term impacts. In the longer-run, there might be no net effect on job losses as workers move from contracting or exiting firms to other firms or other sectors (in particular, the analysis focuses on the manufacturing sector, but affected workers might find jobs in the services sector). Second, to the extent that changes in energy prices or environmental regulations induce a rapid shift in demand (and thus employment) from strictly to less-strictly regulated sectors and regions, estimates of employment losses would be biased upward. The extent of such general equilibrium effects are difficult to estimate, but reduced-form empirical studies should be seen as complementary to general equilibrium models, e.g. Hafstead and Williams $\left(2019_{[5]}\right)$. Therefore the results should be understood as an upper-bound of the true effect of higher energy prices and stricter environmental policies.

10. The analysis demonstrates that there are transition costs in the short run to imposing stricter environmental policies, as some workers are forced to move away from affected firms and sectors. Since these transition costs are typically highly localised in regions specialised in polluting activities, they can also translate into potentially significant regional effects and thus political costs.

\section{Environmental policies and firm employment: Theory and prior evidence}

\subsection{What to expect from a theoretical point of view?}

11. In political debates, the employment effects of rising energy prices or stricter environmental regulation are typically characterised by concerns about potential job losses due to increased compliance and hence production costs, which translate into an output contraction, notably in sectors where energy costs represent a relatively large share of total production costs, such as chemicals, minerals or metals (Figure 2). 
Figure 2. Energy cost shares as percentage of gross output across manufacturing sectors

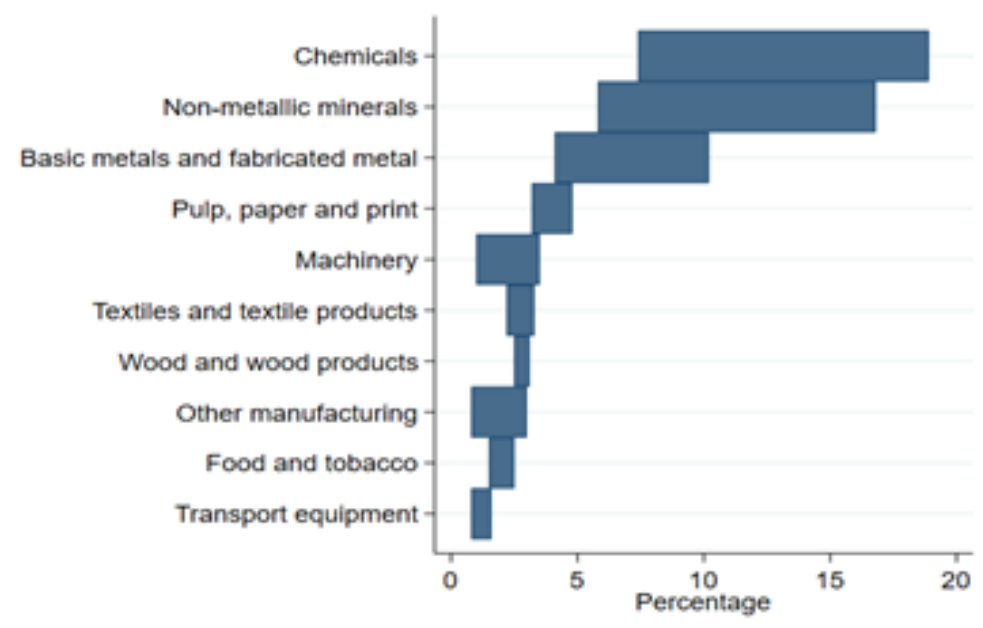

Note: Bars denote percentage ranges for the EU27, China, the United States and Japan. Source: Authors based on European Commission (2014).

12. Theoretically, there are no concerns in the long run, as environmental regulations are expected to induce a substitution between polluting and non-polluting activities without affecting total employment and as wages will eventually adapt. Jobs lost at regulated entities could be offset by hires at non- or less-regulated entities (Fankhäuser, Sehhleier and Stern, 2008 $\left.8_{[6]}\right)$. However, there could well be adjustment costs in the short run as workers move from polluting to cleaner sectors.

13. Deschenes $\left(2018_{[7]}\right)$ highlights two competing factors that may influence the impact of tightened environmental regulation on firm-level employment in the short run. The traditional argument is that as production costs rise because of stricter environmental regulation, output prices will rise, quantity demanded will fall, and firms will reduce employment (the output effect). However, since pollution abatement equipment installed to cope with environmental regulation typically does not increase productivity, these investments effectively translate into an increase in the rental rate of productive capital, which should induce a shift away from capital and towards labour (a substitution effect). This substitution effect would positively affect employment. In fact, pollution abatement activities might also directly require labour input, either at regulated plants or higher up the technology supply chain. Thus, the effect of environmental regulation on short-run employment depends on the relative labour intensity of polluting and non-polluting activities (Morgenstern, Pizer and Shih, 2002 $[1]$ ).

14. While the direction of the demand effect is clearly negative on average, there may be differences in market power across industries that determine the degree to which firms in a sector can pass the extra costs associated with environmental policy to consumers of their products. Less competitive industries with inelastic demand may be less concerned about cost increases associated with regulation. Moreover, the magnitude of the demand effect will differ depending on the sector's energy intensity, which is small for most industries, as shown in Figure 2.

15. Since the factors highlighted above go in opposite directions, the employment impacts at the aggregate level are a priori undetermined even in the short run, and will 
depend on whether the demand or the substitution effect dominates. Therefore, the employment impacts of stricter environmental policies is essentially an empirical question.

\subsection{Previous empirical evidence}

16. The available empirical evidence suggests that environmental regulations sometimes induce job losses, but that the effect is small overall and that jobs are reallocated across firms and sectors rather than permanently lost (for a review, see Deschenes $\left.\left(2018_{[7]}\right)\right)$.

\subsubsection{Impact of energy prices and carbon pricing}

17. Few studies have looked at the impact of energy prices on employment. Deschenes $\left(2011_{[8]}\right)$ finds low price elasticities for electricity, concluding that employment rates are weakly related to electricity prices: a $1 \%$ increase in electricity prices leads to a change in full-time equivalent employment in the manufacturing sector by around $-0.1 \%$. Kahn and Mansur $\left(2013_{[9]}\right)$ exploit variation in energy prices among adjacent US counties and use a relatively long panel (1998-2009). They find evidence that energy-intensive sectors locate in low electricity-price areas. The effects are modest for the typical manufacturing industry, but the most electricity-intensive industry, primary metals, has a large electricity price elasticity of employment of -1.65 .

18. Most studies focus on the manufacturing sector, but Hille and Möbius (2019[10]) look at the whole economy in a cross-country setting. They find a statistically insignificant impact of higher energy prices in the manufacturing sector but a positive effect when all sectors are considered. They explain this net positive effect by job creation in sectors producing and installing pollution abatement technologies and providing energy consulting services.

19. The recent introduction of carbon pricing in several regions of the world provides a direct test of the impact of climate change policies on employment. Most studies have examined the impact of the European Union Emissions Trading System (EU ETS) on employment. Overall, there is no evidence that the EU ETS might have negatively affected the economic performance of regulated firms (see for example Anger and Oberndorfer (2008 $\left.{ }_{[11]}\right)$; Martin, Muûls and Wagner $\left(2015_{[12]}\right)$; Dechezleprêtre et al. $\left.\left(2019_{[13]}\right)\right)$. In the largest study conducted so far covering the whole of Europe for the period 2000-15, Dechezleprêtre, Nachtigall and Venmans $\left(2018_{[14]}\right)$ show that the EU ETS did not affect the employment level of regulated companies negatively, compared to similar but unregulated firms operating in the same sector and country.

20. It is important to keep in mind that the labour market consequences of climate change policies crucially depend on the design of such policies. For example, in 2008, the Canadian province of British Columbia introduced a revenue-neutral carbon tax, whereby the product of the tax is redistributed to households and firms. Yamazaki $\left(2017_{[15]}\right)$ analyses the impact of this carbon tax by comparing employment in British Columbia and in other Canadian provinces. The study finds that the carbon tax had a small positive effect on aggregate employment in British Columbia, which can be explained by a positive impact of the redistribution of the tax proceeds. The effects are, however, heterogeneous, with employment falling in carbon-intensive sectors in response to the tax but increasing in less carbon-intensive sectors (notably services). 


\subsubsection{Impact of other environmental regulations}

21. Early studies on the topic focused on particular sectors and are thus not easily generalised. For example, Berman and Bui $\left(2001_{[16]}\right)$ compare petroleum refineries in the Los Angeles area, subject to some of the strictest air pollution regulations in the United States, to all other refineries in the country. They find no evidence that environmental regulation decreased labour demand, even allowing for induced plant exit and dissuaded plant entry. They actually find weak evidence that regulations may have resulted in a small net increase in employment, possibly because more labour is required for pollution control activities. The lower bound of their estimates implies fewer than 3500 jobs lost due to regulation over 12 years, a number, as the authors note, equivalent to the estimated deaths every year from air pollution in counties not complying with national standards in the mid1980s.

22. A widely-used proxy for the stringency of environmental regulation in early studies was pollution abatement operating costs. Morgenstern, Pizer and Shih (2002 $\left.{ }_{[1]}\right)$ find that higher environmental spending generally does not cause a statistically significant change in employment. There are even statistically significant and positive effects in two industries, but the total number of affected jobs remains quite small. These estimates suggest that, at most, environmental regulation accounted for $2 \%$ of the observed decline in manufacturing employment from 1984 to 1994. Similarly, Cole and Elliott (2007 $\left.{ }_{[17]}\right)$ use data for 1999-2003 covering 27 industries in the United Kingdom and find no evidence that environmental regulations reduce employment. Belova et al. $\left(2013_{[18]}\right)$ also use pollution abatement operating costs as a measure of environmental regulatory stringency and find no evidence of negative employment effects from environmental regulations.

23. The most rigorous studies use installation or county-level data from the United States and focus on the impact of the Clean Air Act Amendments, which impose more stringent pollution control regulations on US counties failing to reach minimum air quality standards and thus considered in "non-attainment". This provides a plausibly more exogenous measure of environmental regulatory stringency than pollution abatement costs. Using a long panel of plant level data (1972-87), Greenstone (2001 $\left.{ }_{[19]}\right)$ finds that the Clean Air Act Amendments of the 1970s led to a loss of around 590000 jobs in strictly regulated non-attainment counties relative to attainment ones (subject to more lenient regulation). This represents $3.4 \%$ of manufacturing employment in the United States and less than $0.5 \%$ of total employment. However, part of this lost activity in non-attainment counties may have moved to attainment counties, so that the net national effect on employment is likely to be smaller.

24. Moreover, many of these job losses are unlikely to be permanent as laid-off workers ultimately find other jobs. Walker (2013 [20]) estimates the transitional costs from the Clean Air Act Amendments. He finds that the average worker in a regulated sector experienced a total earnings loss equivalent to $20 \%$ of their pre-regulatory annual earnings. Almost all of the estimated earnings losses are driven by unemployment spells. Importantly, the total forgone wage bill associated with this regulation-induced sectoral shift in production, estimated to be 5.4 billion USD (in 1990 dollars), is two orders of magnitude below most estimates of the health benefits of the 1990 Clean Air Act Amendments.

25. It is interesting to note that some studies, also focusing on the US Clean Air Act, do not find evidence for such negative impacts of environmental regulation on employment For example, Ferris, Shadbegian and Wolverton $\left(2014_{[21]}\right)$ examine the employment effects of Phase I of the Title IV cap-and-trade programme for $\mathrm{SO}_{2}$ emissions implemented under the 1990 Clean Air Act Amendments (CAAAs). Using a panel dataset of 131 regulated and 
393 unregulated plants, they find that employment is significantly lower in regulated plants than in non-regulated plants, but only in the first year of compliance. This effect is only statistically significant at the $10 \%$ level, though, and is statistically insignificant when aggregating data at the utility level, suggesting firms might be simply relocating employees between plants.

26. To sum-up, the literature has found either negative or no effects of energy prices or environmental regulations on employment. The effects are unsurprisingly more negative in in pollution-intensive sectors, but even in these sectors, the magnitude of the impact appears small compared to the typical turnover in the industry. In the United States for example - where the labour market is dynamic - each industry typically replaces $40 \%$ of its workers each year (Hafstead and Williams, 2019 ${ }_{[5]}$ ). Moreover, these job losses are transitional rather than permanent, so that "the appropriate measure of regulatory costs to the workforce should not be characterized by jobs lost but by transitional costs associated with reallocating production or workers" (Walker, 2011 $\left.1_{[2]}\right]$. Finally, it is worth keeping in mind that the social costs of job losses appear much smaller than the health benefits from environmental regulations and typically represent less than $10 \%$ of other social costs of regulations, so that including job losses in cost-benefit analyses of existing environmental regulations is unlikely to change their conclusions (Bartik, 2013 ${ }_{[23]}$ ).

\section{Sector-level analysis}

27. This section focuses on how increasing energy prices and stricter environmental policy affect aggregate employment at the sector level. It further identifies channels through which environmental policy can affect employment, notably through its effects on firm exit and entry. Employment changes within surviving firms are analysed in Section 4.

\subsection{Methodology}

28. In order to assess the impact of energy prices and environmental policy stringency on aggregate employment, the following model is estimated using panel fixed effects linear regression:

$y_{c s t}=\beta_{p} \ln \left(p_{c s t-1}\right)+\beta_{s} \ln \left(s_{c t-1}\right)+\beta_{w} \ln \left(w_{c s t-1}\right)+\beta_{x} X_{c s t-1}+\alpha_{c s}+\delta_{t}+\chi_{s t}+\mu_{c t}+\varepsilon_{c s t}$

29. The dependent variable $y_{c s t}$ is the $\log$ of employment in country $c$, sector $s$ and year $t$. The variables $p_{c s t-1}, s_{c t-1}$ and $w_{c s t-1}$ are respectively the energy price (explained in detail below), the environmental policy stringency indicator and the average labour compensation per hour worked in sector $s$ and country $c$ in year $t-1$. In this baseline specification, all explanatory variables are lagged by one year to reduce problems related to reverse causality and to account for potential time lags in the effect of energy prices and environmental stringency on employment, but we consider alternatives. This specification has been previously employed by many other authors (e.g. Hille and Möbius $\left(2019_{[10]}\right)$ ). We also consider versions of the baseline specification where the energy price and the environmental policy stringency index enter the equation separately, but the results are not affected by this, as within-country-sector changes in these variables are uncorrelated with each other. 
30. The price of energy is defined as:

$$
\ln \left(P_{c s t}^{k}\right)=\sum_{k} w_{c s}^{k} \ln \left(P_{c t}^{k}\right)
$$

Where $P_{c t}^{k}$ is the price of fuel type $k$ in country $c$ at time $t$, and $w_{c s}^{k}$ is the consumption share of fuel type $k$ in sector $s$. Consumption shares are based on the year 2005 and are kept fixed over time to ensure that energy price changes only come from changes in fuel prices, and not from changes in the mix of fuel inputs that could result from technological change or other industry-specific shocks. ${ }^{3}$

31. Labour compensation is defined as total compensation of employees divided by total hours worked by employees. Compensation of employees is the sum of gross wages and salaries and employers' social security contributions. $w_{c s t-1}$ controls for differences in labour costs across countries and sectors.

32. All estimations include two additional sector-specific control variables $X_{\text {cst-1 }}(\log$ of capital and $\log$ of value added per worker ${ }^{4}$ ), which are lagged to mitigate problems related to simultaneity, ${ }^{5}$ as well as country-sector fixed effects $\alpha_{c s}$ which control for timeinvariant differences across countries and sectors which might be correlated with both employment and energy prices, such as the structure of sectors. Larger or more concentrated sectors, for example, may be able to obtain lower energy prices on average. All estimations also include year fixed effects $\left(\delta_{t}\right)$ to control for global shocks that affect all sectors and countries in a similar way. Quadratic country trends $\mu_{c t}$ capture macroeconomic trends at the national level, for example the effects of increasing globalisation and trade openness (e.g. China entering the World Trade Organisation) or differences in labour taxation, whereas quadratic sector trends $\chi_{s t}$ capture sector-specific trends and shocks, such as global changes in demand for products coming from a particular sector.

\subsection{Data sources and descriptive statistics}

33. Industrial energy prices are obtained from Sato et al. $\left(2019_{[24]}\right)$. The database covers energy prices for 12 industrial sectors ( 11 of them in manufacturing) from 48 countries for the period 1995 to 2015. The energy price index is based on fuel price data for oil, gas, coal and electricity, and their sectoral consumption shares come from the IEA Energy End-Use Prices database. This analysis uses the energy prices with fixed consumption shares, implying that the index's variation exclusively originates from variation in fuel prices and taxes and does not depend on the technological choices of sectors and firms adapting to a changing price environment.

34. Information about environmental policy stringency comes from OECD's EPS indicator $\left(\mathrm{OECD}, 2019_{[25]}\right)$. The EPS covers almost all OECD and G20 countries over the period 1990 - 2015. It combines information on 14 market-based and non-market-based

3. Using different base years for the consumption shares of fossil fuels do not alter the results. The results are reported in the robustness checks.

4. With labour compensation already controlled for, this might appear redundant. We keep this variable for consistency with the firm-level analysis (see Section 4), but the results are insensitive to removing it.

5. Estimating equation (1) with contemporaneous sector-specific control variables does not change the results. 
policy instruments, regulating primarily $\mathrm{CO}_{2}$ and other air pollutants in the energy and transport sectors. All regulations are aggregated into a single indicator at the country level. The EPS is positively correlated with survey-based measures of perceptions of environmental policy stringency (Botta and Koźluk, 2014 ${ }_{[4]}$ ) and with energy price indices at the country level (Garsous and Kozluk, 2017 [26]).

35. Figure 3 shows the energy price and the EPS in 1995 and 2015 across countries in the final dataset. Two observations are worth making. First, energy prices vary substantially across countries, so concerns about competitiveness impacts of energy price increases are legitimate. For example, in 1995 energy prices in Portugal (the country with the highest energy price in 1995) were up to four times higher than energy prices in Mexico (the country with the lowest energy prices). This ratio decreased to a factor of three until 2015, but remains substantial. Importantly, Sato et al. $\left(2019_{[24]}\right)$ show that taxes play a major role in explaining the variation in energy prices across countries. Specifically, taxes explain between $80 \%$ to $90 \%$ of the cross-country variation for coal, $30 \%$ to $70 \%$ for electricity, $40 \%$ to $80 \%$ for oil and around $20 \%$ for gas. Second, energy prices and EPS have increased in most countries between 1995 and 2015, but not by the same magnitude. On average, energy prices and EPS have increased by respectively $54 \%$ and $82 \%$ between 1995 and 2015 , equivalent to a $2.1 \%$ and $2.8 \%$ increase per year. Most of this time-series variation for energy prices can be attributed to changes in fuel taxes (Sato et al., 2019 [24]). Despite the fact that some countries provide tax exemptions or rebate schemes for their domestic energy-intensive industry to level the playing field, the pace of energy price hikes varies considerably across countries. These changes at a different pace are crucial for this paper's identification strategy, which is based on the within-country-sector variation of energy prices and EPS. Finally, it is also important to highlight that the year-on-year variation of energy prices and EPS is virtually uncorrelated, which is reassuring for the estimation of employment effects using both variables jointly (Figure A.1).

36. Employment data at the country-sector-year level are obtained from the socioeconomic accounts of the World Input Output Database (WIOD). ${ }^{6}$ WIOD covers 43 countries and 19 different sectors in the manufacturing sectors, based on NACE 2-digit codes, from 2000 to 2014. These sectors can be mapped to the sectors covered by(Sato et al. (2019[24]). The database also provides information on total hours worked, labour compensation, gross value added, nominal capital stock, and price levels. They are used to compute the control variables (real hourly wage, value added per worker and the capital stock).

6. http://www.wiod.org/database/seas16. 
Figure 3. Energy price and EPS across OECD countries in 1995 and 2015

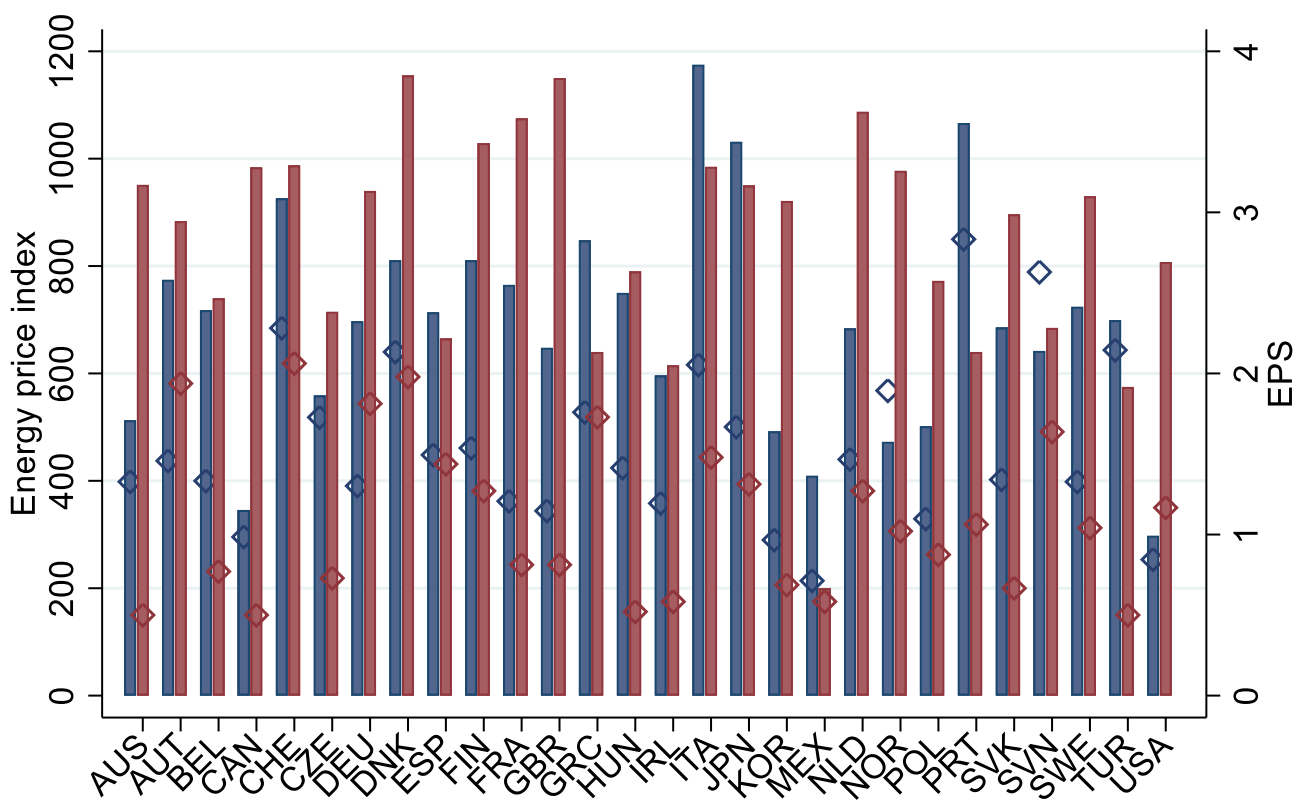

Energy price $2015 \diamond$ Energy price 1995

EPS 2015

$\diamond$ EPS 1995

Note: The figure depicts values for 1995 or the earliest data available after 1995 and 2015 or the latest data available before 2015 .

Source: Authors.

37. Descriptive statistics for the variables used in the sector-level regressions are shown in Table 1.

Table 1. Descriptive statistics

\begin{tabular}{|c|c|c|c|c|c|c|c|c|}
\hline Variable & Unit & Source & Coverage & Mean & $\begin{array}{l}\text { Standard } \\
\text { deviation }\end{array}$ & Median & Minimum & Maximum \\
\hline Employment & Log thousands & WIOD (2016) & $\begin{array}{c}2000-14 ; \\
43 \text { countries; } \\
19 \text { sectors }\end{array}$ & 3.51 & 1.74 & 3.53 & -4.61 & 7.49 \\
\hline Energy price & Log of energy price index & $\begin{array}{l}\text { Sato et al. } \\
\text { (2019) }\end{array}$ & $\begin{array}{l}1995-2015 \\
48 \text { countries; } \\
11 \text { sectors }\end{array}$ & 6.43 & 0.40 & 6.45 & 5.12 & 7.60 \\
\hline EPS & Log of EPS index & $\begin{array}{l}(\mathrm{OECD} \\
\left.2019_{[25]}\right)\end{array}$ & $\begin{array}{l}1990 \text { - 2015; } \\
34 \text { countries; } \\
\text { country level; }\end{array}$ & 0.72 & 0.45 & 0.82 & -0.47 & 1.42 \\
\hline Wage & $\begin{array}{c}\text { Log of real labour } \\
\text { compensation (national } \\
\text { currency) }\end{array}$ & WIOD (2016) & $\begin{array}{l}2000-14 \\
43 \text { countries; } \\
19 \text { sectors }\end{array}$ & 3.87 & 1.85 & 3.41 & -0.16 & 11.13 \\
\hline Capital & $\begin{array}{c}\text { Log of capital (millions of } \\
\text { national currency) }\end{array}$ & WIOD (2016) & $\begin{array}{l}2000-14 \\
43 \text { countries; } \\
19 \text { sectors }\end{array}$ & 9.15 & 2.94 & 8.92 & -2.04 & 19.76 \\
\hline $\begin{array}{l}\text { Value added } \\
\text { per worker }\end{array}$ & $\begin{array}{l}\text { Log of value added } \\
\text { (thousands of national } \\
\text { currency) }\end{array}$ & WIOD (2016) & $\begin{array}{l}2000-14 \\
43 \text { countries; } \\
19 \text { sectors }\end{array}$ & 5.11 & 1.98 & 4.46 & 0.52 & 13.45 \\
\hline
\end{tabular}

Source: Authors. 


\subsection{Results}

38. The baseline sample consists of all OECD countries in order to be consistent both with the firm-level analysis presented in Section 4 and with the entry and exit analysis in Section 5. We first present the general findings (Section 3.3.1) before exploring heterogeneous effects across sectors (Section 3.3.2).

\subsubsection{Baseline results}

39. Table 2 shows the results of the baseline estimations. ${ }^{7}$ Column (1) shows regression results of the effect of energy prices and EPS simultaneously on total sector employment, while in columns 2 and 3 these variables enter separately. The results show that the impact of higher energy prices and stricter EPS on employment is negative and statistically significant, but small in magnitude. The coefficient of -0.07 and -0.054 for the energy price variable implies that a $10 \%$ increase in the energy price would reduce employment by 0.7 and $0.54 \% .{ }^{8}$ Recall that energy prices increased by $2.1 \%$ per year on average during the sample period, so a $10 \%$ increase in energy prices is large and is experienced every 4 to 5 years for the average OECD country. Similarly, a $10 \%$ increase in EPS reduces sectorlevel employment by $0.49-0.58 \%$ depending on the specification. Compared to energy prices, a 10\% increase of EPS is more typical. For example, the introduction of the carbon emissions trading scheme in the European Union was associated with an increase of the EPS indicator by $22 \%$ in European countries.

40. Overall, the contribution of energy price increases on aggregate employment in the manufacturing sector appears small. The model implies that between 2000 and 2014, around 100000 workers per year across all OECD countries lost their job because of rising energy prices. This number might look large, but it represents only $0.16 \%$ of the average manufacturing workforce in the sample period. Moreover, these job losses might be partially or completely offset by hires in non-manufacturing sectors.

41. Focusing on the United States, we can compare the estimated effect with other factors affecting manufacturing employment reported in the literature. The model implies that between 2000 and 2014, around 15000 workers per year lost their job because of rising energy prices. In comparison, trade openness to China has been estimated to be responsible for 78000 annual manufacturing job losses (Caliendo, Dvorkin and Parro, 2019[27]) and robotisation for between 21000 and 39000 (Acemoglu and Restrepo, 2017 $[28]$ ).

7. We apply weights in our regressions equal to the average number of employees in each countrysector. Hence, all coefficients in Table 2 can be interpreted as the impact on the average countrysector, irrespective of its total number of employees.

8. These results are different from those found by Hille and Möbius $\left(2019_{[10]}\right)$, who report a positive although not significant employment effect of higher energy prices for the manufacturing sector. One reason for this result can be that Hille and Möbius $\left(2019_{[10]}\right)$ do not include country and sector trends to control for country and sector-specific developments (e.g. technological change) that can affect both energy prices and employment (Section 2). Removing country and sector trends in our model leads to a point estimate of the energy price coefficient of +0.003 , suggesting that these trends absorb some of the unobserved heterogeneity that is correlated with energy prices and employment. 
Table 2. Effect of energy prices and EPS on employment

\begin{tabular}{|c|c|c|c|}
\hline Dep. Variable: Log of employment (t) & (1) & (2) & (3) \\
\hline Log energy price $(t-1)$ & $-0.070^{\star *}$ & $-0.054^{*}$ & \\
\hline & $(0.032)$ & $(0.029)$ & \\
\hline $\log$ EPS $(t-1)$ & $-0.058^{\star \star \star}$ & & $-0.049^{* * \star}$ \\
\hline & $(0.015)$ & & $(0.014)$ \\
\hline Log hourly wage ( $\mathrm{t}-1)$ & $-0.115^{\star \star \star}$ & $-0.107^{* \star}$ & $-0.113^{* * \star}$ \\
\hline & $(0.041)$ & $(0.042)$ & $(0.040)$ \\
\hline Log capital (t - 1) & $0.187^{\star * *}$ & $0.207^{\star * *}$ & $0.185^{\star * *}$ \\
\hline & $(0.042)$ & $(0.041)$ & $(0.041)$ \\
\hline Log value added per worker $(t-1)$ & -0.014 & -0.022 & -0.013 \\
\hline & $(0.039)$ & $(0.038)$ & $(0.039)$ \\
\hline Country quadratic trends & Yes & Yes & Yes \\
\hline Sector quadratic trends & Yes & Yes & Yes \\
\hline \# Observations & 6494 & 7502 & 6566 \\
\hline \# Country-sectors & 518 & 536 & 526 \\
\hline
\end{tabular}

Note: Regressions are estimated by the fixed-effects estimator on an unbalanced panel. Robust standard errors are shown in parentheses and are clustered at the sector-country level. Significance levels are given by: $* \mathrm{p}<0.1$, $* * \mathrm{p}<0.05$ and $* * * \mathrm{p}<0.01$. All regressions include linear and quadratic country and sector trends.

Source: Authors.

42. The coefficients of the control variables have the expected sign. The coefficient of hourly wage is negative and significant. Firms decrease employment in response to increasing labour costs - in line with economic theory. Moreover, the wage coefficient (i.e. the elasticity of employment with respect to hourly wages) is around twice as large as the energy price and the EPS coefficients. Increases in capital increase the demand for labour, suggesting that capital and labour are complements rather than substitutes. Increases in labour productivity, measured as value added per worker, reduce the demand for labour, but the effect is small and not statistically significant, not surprisingly so since the average hourly wage is already controlled for.

43. The results are robust to a range of different specifications (Table 3 in Box 1), including the use of different sets of control variables, different lag structures, different estimation techniques and the exclusion of outliers. The point estimate for energy price is negative in all cases, ranging from -0.033 to -0.137 and always statistically significant, except when a demanding full set of country by year and sector by year fixed effects are included, which decreases precision. The range of coefficients on the EPS variable varies from -0.065 to 0.045 and is statistically significant in almost all specifications. In addition, the existence of non-linear effects of energy prices and EPS was tested in various ways but no evidence of non-linearity was found.

44. Interestingly, the effect of stricter environmental stringency on employment is lower for market-based instruments relative to command-and-control instruments. The construction of the EPS allows for distinguishing its market-based component (e.g. taxes, emissions trading schemes, feed-in-tariffs) from its command-and-control component (e.g. emission limit values) of environmental stringency. The results suggest that a $10 \%$ increase in the market-based component of EPS reduces sector-level employment by 0.08 to $0.13 \%$ whereas the same increase in the non market-based component reduces employment by between 0.39 and $0.44 \%$ (Table A.1). Market-based environmental policy instruments, which are based on explicit price signals (e.g. taxes, cap and trade systems), are generally considered to be more cost-effective than non-market instruments such as e.g. bans or 
technology standards (de Serres, Murtin and Nicoletti, 2010 ${ }_{[29]}$ ). The use of these instruments can therefore be expected to limit the potentially detrimental impacts of environmental policies. This is mainly because, under a market-based mechanism, firms have more flexibility in choosing the technology and timing of adjustment, than in a scheme of rigid performance standards.

\section{Box 1. Robustness of sector-level results}

The robustness of the results are checked using a set of different specifications:

\section{Control variables}

In addition to sector and country quadratic trends, we add several country-level control variables: economic output (GDP) as well as public expenditure on labour markets (which include unemployment benefits, training, employment incentives, ALMPs, incentives for start-up businesses and early retirement programmes) to better control for time-varying country-specific heterogeneity. In addition, we also experiment with removing sector-level control variables (which could remove too much of the variation in energy prices) and substituting real hourly wages by unit labour costs. None of these changes make any noticeable difference to the point estimates.

\section{Accounting for unobserved sector and country shocks}

The baseline regression includes linear and quadratic country and sector trends to account for sectorspecific and country-specific shocks. A number of different specifications are tried: replacing quadratic with either linear or cubic trends or with country-year and sector-year fixed effects which are the best (but most demanding) way of controlling for unobserved shocks. The results are robust to these various tests, but the coefficient on energy prices becomes statistically insignificant when both country-year and sector-year fixed effects are included - a highly demanding specification given that energy prices vary at the country-sector-year level. It is however not statistically different from the baseline, but slightly larger in magnitude at -0.116 .

\section{Different lag structure}

We lagged the explanatory variables by one year in the baseline regression to reduce problems related to reverse causality. Changes in energy prices, however, may affect employment with a longer delay. To address this problem, we estimate a distributed lag model which includes a linear combination of the explanatory variables lagged by one and two years. The impact after 2 years is slightly larger than the one-year impact, but not by much, suggesting that impacts fade away rapidly. We also report the contemporaneous effect of the energy price and EPS on employment, which is statistically insignificant. The 3-year lags are statistically insignificant (not reported).

\section{Alternative explanatory variables}

For energy price, the baseline specification uses the fixed weight energy price (FEPI) index with fossil fuel consumption shares from 2005. Testing different base years (i.e. 1995, 2000, 2010, or using the average share between 1995 and 2014) does not change the qualitative results. In addition, the variable weights energy price level (VEPL) is tested to control for changes in the composition of fuels as a response to increased energy prices and technological change. The VEPL, provided by Sato et al. $\left(2019_{[24]}\right)$, takes annual changes in fuel composition into account and provides a more precise estimate of true energy prices at the sector-year level, but introduces endogeneity problems in the regression framework, as firms' decisions regarding employment and fuel composition are determined simultaneously. The effect of an increase in VEPL on employment is very similar to that of FEPI, suggesting that fuel switching does not represent a significant adjustment margin for the average sector. 


\section{Sensitivity to outliers}

Outliers (e.g. due to measurement error) can have large effects on the point estimates. This problem is addressed by excluding the $1 \%$ largest observations in terms of average country-sector employment from the regression. This leaves the main coefficients virtually unaffected.

\section{Alternative estimation technique}

As an alternative to the usual fixed effects estimator used for the baseline model, we also estimate the model in first differences. First differences also control for unobserved heterogeneity, but require less strict assumptions on the exogeneity of explanatory variables. Interestingly, the main coefficient decreases significantly for both energy prices and EPS, suggesting that our baseline estimates might be an upper bound of the true effect. To be conservative, we use the within-group estimator as the baseline.

Table 3. Robustness of sector-level baseline regression

\begin{tabular}{|c|c|c|c|}
\hline Dimension & Robustness check & Energy price coefficient & EPS coefficient \\
\hline \multicolumn{4}{|l|}{ Control variables } \\
\hline & No sector-level control variables & $-0.057^{*}$ & $-0.056^{\star \star *}$ \\
\hline & Adding country-level controls & $-0.074^{* *}$ & $-0.056^{* \star *}$ \\
\hline & Substituting real wage by unit labour cost & $-0.070^{* *}$ & $-0.055^{\star * *}$ \\
\hline \multicolumn{4}{|l|}{ Country and sector controls } \\
\hline & Linear time trends & $-0.085^{\star * *}$ & $-0.050^{* \star *}$ \\
\hline & Linear country-sector trend & $-0.078^{* * *}$ & $-0.050^{\star * *}$ \\
\hline & Cubic time trends & $-0.066^{*}$ & $-0.035^{\star \star *}$ \\
\hline & Sector-year fixed effects & $-0.069^{*}$ & $-0.036^{* \star *}$ \\
\hline & Country-year fixed effects $\$$ & $-0.118^{*}$ & 0.044 \\
\hline & Sector-year and country-year FE\$ & -0.116 & 0.045 \\
\hline \multicolumn{4}{|l|}{ Lag structure } \\
\hline & No lag & -0.059 & -0.012 \\
\hline & Lag1 + Lag2 & $-0.099^{* *}$ & $-0.089^{* \star *}$ \\
\hline \multicolumn{4}{|l|}{ Alternative explanatory variables } \\
\hline & Different base years of cons. shares & $-0.068^{* *}$ to $-0.086^{* *}$ & NA \\
\hline & VEPL & $-0.079^{\star *}$ & NA \\
\hline \multicolumn{4}{|l|}{ Outliers } \\
\hline \multirow{3}{*}{ Alternative estimation technique } & Remove largest $1 \%$ of employment & $-0.067^{* *}$ & $-0.060^{* \star *}$ \\
\hline & & & \\
\hline & First differences & $-0.033^{*}$ & 0.000 \\
\hline
\end{tabular}

Note: Regressions are estimated by the fixed-effects estimator on an unbalanced panel. Robust standard errors are shown in parentheses and are clustered at the sector-country level. Significance levels are given by: ${ }^{*} \mathrm{p}<0.1$, $* * \mathrm{p}<0.05$ and $* * * \mathrm{p}<0.01$. All regressions include linear and quadratic country and sector trends.

\$: Estimating a regression with country-year fixed effects would prevent estimating the EPS coefficient as country-year fixed effects are collinear with the EPS variable which varies only at the country level. Hence, in this specification the EPS is interacted with energy intensity (see Section 4.1. for details).

Source: Authors. 


\subsubsection{Heterogeneity across sectors}

45. The impact of energy prices on employment varies substantially across sectors. Figure 4 shows the coefficient of sector-specific dummy variables interacted with the lagged $(\log )$ energy price index and the associated $90 \%$ confidence intervals. As expected, the largest point estimates are observed in the most energy-intensive sectors: iron and steel, chemicals and petrochemicals, non-ferrous metals, and non-metallic minerals. Apart from non-metallic minerals, the effects are statistically significant at the $10 \%$ level for all these energy-intensive sectors, implying that increased energy prices have negative short-term impacts on employment in these sectors. A negative and statistically significant effect is also found for transport equipment. None of the sectors in our analysis show positive and statistically significant effects of energy price increases, implying that reallocation of labour towards less energy-intensive sectors is limited, even though such reallocation might happen toward non-manufacturing sectors. The impact of EPS on employment across sectors are qualitatively similar: energy-intensive sectors tend to be affected the most, but the most negative coefficient is found for the transport equipment sector, which sells products most affected by environmental regulations (see Figure A.2).

46. Notably, the size of the employment effect is moderate even in the most heavily affected sectors. The estimated coefficients range from -0.19 to +0.01 . To put these coefficients in perspective, consider the iron and steel sector (i.e. the most affected sector with a coefficient of -0.19) in the United States. Between 2000 and 2014, US energy prices in this sector increased by $20 \%$. According to our model, a coefficient of -0.19 would translate into slightly more than 1000 lost jobs per year, accounting for around $7 \%$ of total employment losses in the US steel sector during that period.

Figure 4. The employment effects of higher energy prices differ across sectors

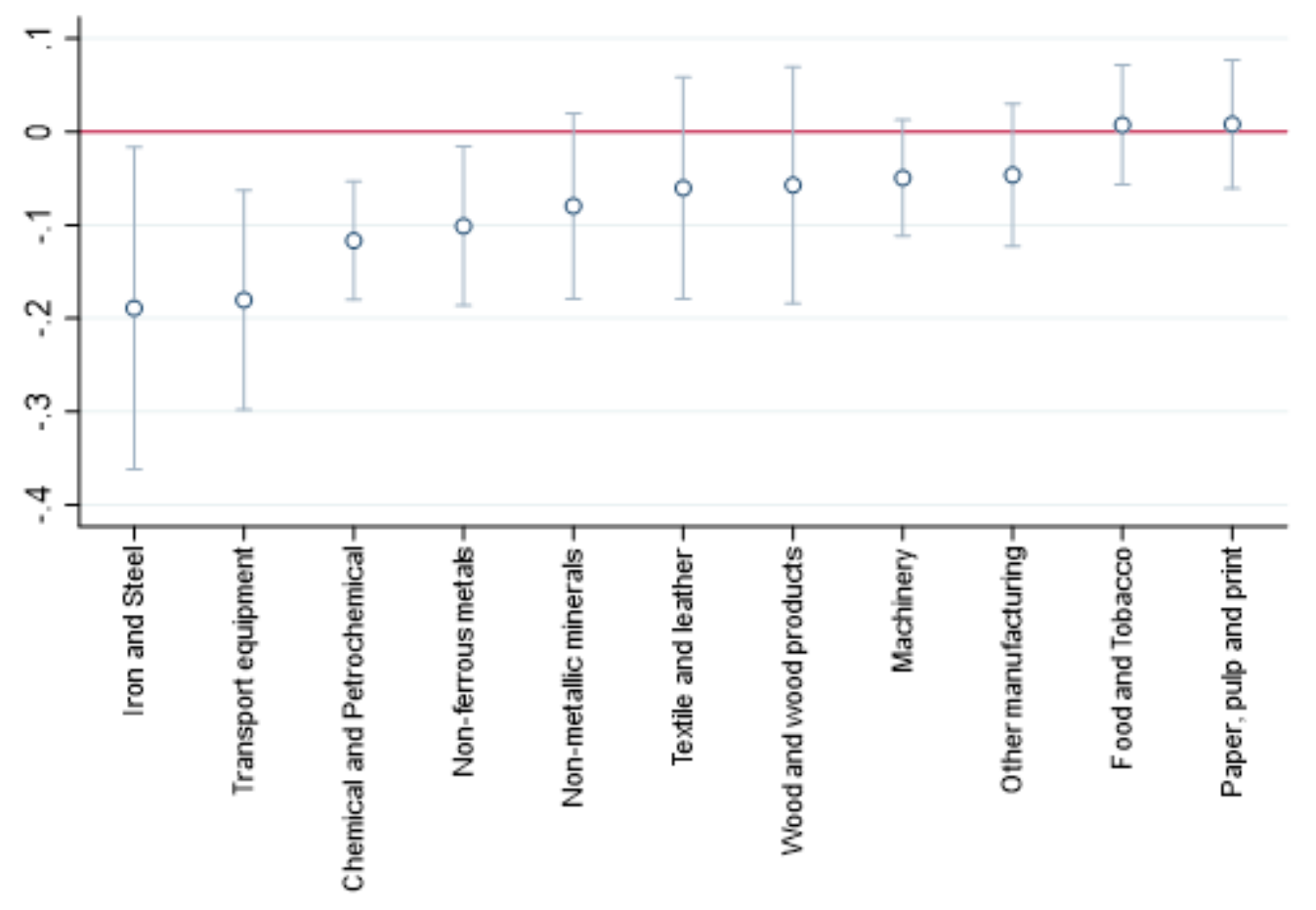

Source: Authors. 


\section{Firm-level results}

47. The previous section showed that higher energy prices and more stringent environmental policies affect aggregate employment negatively at the sector level. Three channels could be responsible for this result: (i) increases in energy prices reduce the average employment of (surviving) firms; (ii) increases in energy prices accelerate firm exit; (iii) increases in energy prices deter firm entry. This section sheds more light on the employment dynamics of surviving firms using ORBIS, a global firm-level database.

\subsection{Methodology}

48. The following model is estimated to assess the effect of rising energy prices and increasing environmental policy stringency on employment:

$$
\begin{gathered}
\ln \left(e m p_{i t}\right)=\beta_{p} \ln \left(p_{c s t-1}\right)+\beta_{e} E I_{s} \ln E P S_{c t-1}+\beta_{w} \ln \left(w_{c s t-1}\right)+\beta_{x} X_{i t-1}+\xi_{i}+\chi_{s t} \\
+\mu_{c t}+\varepsilon_{i t}(2)
\end{gathered}
$$

49. The dependent variable is $\ln \left(e m p_{i t}\right)$ defined as the log employment of firm $i$ in year $t, p_{c s t-1}$ is the energy price in sector $s$ and country $c$ in year $t, E I_{s} \ln E P S_{c t-1}$ is the energy intensity of sector $s$ interacted with the EPS in country $c$ and year $t$ (see below for further explanation) and $w_{c s t}$ is the average hourly labour compensation (wage + social security contributions) in sector $s$, country $c$ and year $t$. All estimations include firmspecific control variables $X_{i t-1}$, including the log of capital and the log of value added per worker, as well as firm fixed effects $\left(\xi_{i}\right)$ to capture any time-invariant differences across firms, which might be correlated with both employment and energy prices, such as the ability of larger (and more productive) firms to obtain lower average energy prices. The size of the firm-level dataset also allows for including sector-year fixed effects $\left(\chi_{s t}\right)$ and country-year fixed effects $\left.\left(\mu_{c t}\right)\right)^{9}$ Country-year fixed effects control for any macroeconomic changes at the country level, such as GDP fluctuations or differences in labour taxation that might be correlated with energy prices and employment. Sector-year fixed effects capture any sector-level changes in macroeconomic conditions such as changes in the global demand for goods from this particular sector. We define sectors at the NACE 4-digit level - the most granular sector definition possible..$^{10}$ Even after including these sector-year fixed effects at this level of granularity, there remains enough variation in energy prices to estimate the effect of energy price changes on firm-level employment (see Figure A.3).

50. The model is implementable for energy prices and labour compensation which vary at the sector-country level but would fail to identify the effect of the EPS, which only varies at the country-year level. Therefore, in equation (2) the EPS is interacted with the energy intensity of sector $s$ following the approach of Rajan and Zingales $\left(1998_{[30]}\right)$. The identification is based on the assumption that the impact of environmental policy on employment increases with the sector's exposure to environmental regulation, which should be correlated with the sector-specific energy intensity.

9. The STATA command reghdfe is used to estimate fixed effects linear regression models in the presence of large numbers of fixed effects (Abowd, Creecy and Kramarz, 2002 [34]).

10. To get an impression of how granular NACE 4-digit code is, consider the manufacturing of glass and glass products which is broken down to Manufacture of flat glass (NACE Code 2311), Shaping and processing of flat glass (2312), Manufacture of hollow glass (2313), Manufacture of glass fibres (2314), and Manufacture and processing of other glass, including technical glassware (2319). 
51. In the baseline specification, all explanatory variables are lagged by one year to mitigate concerns related to reverse causality and simultaneity as in the sector-level analysis, but alternative lag structures are considered in the robustness analysis. As in the previous sections, we estimate the effect of energy prices and EPS both simultaneously and separately.

\subsection{Data sources}

52. Data on firm level employment and other firm-level characteristics (value added and capital) are drawn from the OECD version of the ORBIS database maintained by Bureau Van Dijk. ORBIS provides a variety of financial and non-financial data on private companies across the world. The final sample covers almost 500000 firms from 23 OECD countries over the period 2000-2014. Firms belong to 340 sub-sectors at the NACE 4-digit level. Table 4 shows the descriptive statistics for the variables included in the empirical model.

53. It is important to highlight some caveats related to the use of ORBIS. First, the firm population in ORBIS is not representative, but biased towards listed firms that are typically larger and more productive. Second, the coverage of firms varies substantially across countries with almost full coverage in countries such as Italy and Spain and very limited coverage of countries such as the United States (Table A.2).

Table 4. Descriptive statistics: Firm level

\begin{tabular}{|c|c|c|c|c|c|c|c|c|}
\hline Variable & Unit & Source & Coverage & Mean & $\begin{array}{l}\text { Standard } \\
\text { deviation }\end{array}$ & Median & Minimum & Maximum \\
\hline Employment & Log of employment & ORBIS & $\begin{array}{l}1990-2015 ; \\
45 \text { countries; } \\
340 \text { sectors }\end{array}$ & 2.64 & 1.53 & 2.48 & 0.00 & 13.25 \\
\hline \multirow[t]{2}{*}{ Energy price } & Log of energy price index & $\begin{array}{l}\text { Sato et al. } \\
(2019)\end{array}$ & $\begin{array}{l}1995-2015 \\
48 \text { countries; } \\
11 \text { sectors }\end{array}$ & 6.56 & 0.42 & 6.56 & 5.24 & 7.55 \\
\hline & Log of EPS index & $\begin{array}{l}(\mathrm{OECD}, \\
\left.2019_{[25]}\right)\end{array}$ & $\begin{array}{l}1990-2015 \\
34 \text { countries; } \\
\text { country level; }\end{array}$ & 0.94 & 0.26 & 1.01 & -0.21 & 1.42 \\
\hline Wage & $\begin{array}{l}\text { Log of real labour } \\
\text { compensation (national } \\
\text { currency) }\end{array}$ & $\begin{array}{l}\text { WIOD } \\
(2016)\end{array}$ & $\begin{array}{l}2000-14 ; \\
43 \text { countries; } \\
19 \text { sectors }\end{array}$ & 3.79 & 2.09 & 3.07 & 1.42 & 11.13 \\
\hline Capital & Log of capital (USD) & ORBIS & $\begin{array}{l}1990-2015 \\
45 \text { countries; } \\
340 \text { sectors }\end{array}$ & 12.65 & 2.38 & 12.59 & 0.00 & 25.81 \\
\hline $\begin{array}{r}\text { Value added per } \\
\text { worker }\end{array}$ & $\begin{array}{l}\text { Log of value added per } \\
\text { worker (USD) }\end{array}$ & ORBIS & $\begin{array}{l}1990-2015 \\
45 \text { countries; } \\
340 \text { sectors }\end{array}$ & 10.46 & 0.78 & 10.53 & -1.39 & 18.31 \\
\hline
\end{tabular}

Source: Authors.

\subsection{Impacts of energy prices and EPS}

54. Table 5 shows the results of the baseline regressions. ${ }^{11}$ Column 1 regresses firm employment on lagged energy prices and EPS simultaneously while columns 2 and 3 use

11. In contrast to the sector-level analysis, we do not apply weights here as the sample is not representative of the population. Hence, the coefficients can be interpreted as the effect of energy prices and EPS on the average firm. 
energy prices and EPS separately. The results show that higher energy prices have a statistically significant and small positive effect on the employment level of surviving firms. A $10 \%$ increase in energy prices would increase employment of the average surviving firm by $0.66 \%$. This result is in contrast to that of the previous section. Section 5 . offers a potential explanation to reconcile these contrasting results by looking at the effect of energy prices on firm dynamics.

Table 5. Effect of energy prices and EPS on firm-level employment

\begin{tabular}{|c|c|c|c|}
\hline Dep. variable: Log of employment (t) & (1) & (2) & (3) \\
\hline \multirow[t]{2}{*}{ Log energy price $(t-1)$} & $0.066^{* * *}$ & $0.057^{* * *}$ & \\
\hline & $(0.016)$ & $(0.016)$ & \\
\hline \multirow[t]{2}{*}{$\log$ EPS $(t-1)$} & $-0.040^{\star * *}$ & & $-0.031^{* *}$ \\
\hline & $(0.015)$ & & $(0.015)$ \\
\hline \multirow[t]{2}{*}{ Log hourly wage $(t-1)$} & $-0.058^{* * *}$ & $-0.057^{\star * *}$ & $-0.060^{* * *}$ \\
\hline & $(0.008)$ & $(0.008)$ & $(0.008)$ \\
\hline \multirow[t]{2}{*}{ Log capital (t - 1) } & $0.119^{* * *}$ & $0.119^{* * *}$ & $0.119^{* * *}$ \\
\hline & $(0.001)$ & $(0.001)$ & $(0.001)$ \\
\hline \multirow[t]{2}{*}{ Log value added per worker $(t-1)$} & $-0.034^{\star \star *}$ & $-0.034^{\star * *}$ & $-0.034^{* * *}$ \\
\hline & $(0.001)$ & $(0.001)$ & $(0.001)$ \\
\hline Country-year fixed effects & Yes & Yes & Yes \\
\hline Sector-year fixed effects (NACE4) & Yes & Yes & Yes \\
\hline \# Observations & 2510413 & 2510413 & 2510413 \\
\hline \# Firms & 430988 & 430988 & 430988 \\
\hline
\end{tabular}

Note: Regressions are estimated by the fixed-effects estimator on an unbalanced panel. Robust standard errors are shown in parentheses and are clustered at the firm level. Significance levels are given by: $* \mathrm{p}<0.1,{ }^{* *} \mathrm{p}<0.05$ and $* * * \mathrm{p}<0.01$. All regressions include country-year and sector-year fixed effects (NACE4).

Source: Authors.

55. Contrary to energy prices, more stringent environmental policy has a negative, but small effect on firm-level employment that is statistically significant. This result mirrors the result from the previous section where more stringent environmental regulation was found to reduce sector-level employment. When splitting the EPS into its market-based and non-market-based components, the coefficient is not statistically different for the two variables (-0.016 vs -0.018$)$, suggesting both components contribute equally to the negative impact of EPS on firm employment.

56. All coefficients of the control variables are statistically significant and have the expected sign. The coefficient of (sector-level) hourly wages is negative: firms decrease employment in response to increasing labour costs - in line with economic theory. Increases in capital - expansion of production capacity - increase the demand for labour. Increases in firm-level labour productivity, measured as value added per worker, reduce the demand for labour.

57. The coefficients for energy price and EPS are robust to a range of different specifications (Table 6 in Box 2). The point estimate for energy price ranges from +0.014 to +0.074 and is statistically significant at the $1 \%$ level in all cases. The EPS coefficient varies between -0.004 and -0.053 and is statistically significant in most specifications.

58. As explained above, the ORBIS database is not representative of the population of firms operating in OECD countries. Addressing this selection issue, e.g. through weighting, is delicate as some firms may be assigned a disproportionately large weight (Bajgar et al., 
$2020_{[31]}$ ). For example, our final dataset only covers 241 firms in the German iron and steel sector, representing less than $9 \%$ of the entire German steel sector. Weighting would, thus, introduce a new form of bias to the extent that the results may depend on a very small number of (heavily weighted) observations. Reassuringly, re-estimating the baseline regression after sequentially leaving out one country yields coefficients that are always in the same range as those reported in Table 5, suggesting that the results are not driven by a single, overrepresented country (Box 2). It remains that the ORBIS database is also selected toward relatively larger and more productive firms, and the results may not be valid beyond this set of firms which tend to be overrepresented in ORBIS. With this in mind, we conclude that, across OECD countries, a large set of (likely larger, more productive) firms benefit from higher energy prices.

\section{Box 2. Robustness checks for the firm-level analysis}

We use the same robustness checks as outlined in the previous section (Box 1). Note that for the control variables, we do not need to control for additional country-level variables as we already include country-year fixed effects. For the sector-level control variables, we test different NACE levels as a robustness check. We also sequentially leave out each country before re-estimating the baseline regression to control for the sample bias inherent in the dataset. This hardly changes the magnitude and the statistical significance of the coefficients. The coefficients turn insignificant only in one case (EPS, leaving out Korea).

Table 6. Robustness checks for firm-level analysis

\begin{tabular}{|c|c|c|c|}
\hline Dimension & Robustness check & Energy price & EPS \\
\hline \multicolumn{4}{|c|}{ Control variables } \\
\hline & No firm-level control variables & $0.045^{\star * *}$ & $-0.041^{* \star *}$ \\
\hline & Substituting real wage by unit labour cost & $0.074^{* * *}$ & $-0.053^{* * *}$ \\
\hline \multicolumn{4}{|c|}{ Country and sector controls } \\
\hline & NACE3 Sector-year FE & $0.057^{* * *}$ & $-0.033^{* *}$ \\
\hline & NACE2 Sector-year FE & $0.057^{* * *}$ & -0.020 \\
\hline & Cubic time trend (instead of FEs) & $0.014^{\star *}$ & $-0.024^{\star * *}$ \\
\hline \multicolumn{4}{|c|}{ Lag structure } \\
\hline & No lag & $0.054^{* * *}$ & -0.021 \\
\hline & Lag1 + Lag2 & $0.073^{* * *}$ & $-0.039^{* *}$ \\
\hline \multicolumn{4}{|c|}{ Alternative explanatory variables } \\
\hline & Different base years of cons. shares & 0.010 to $0.076^{\star *}$ & NA \\
\hline & VEPL & $0.033^{* *}$ & NA \\
\hline \multicolumn{4}{|c|}{ Outliers and sample } \\
\hline & $\begin{array}{r}\text { Remove largest } 1 \% \text { firms in terms of } \\
\text { employment }\end{array}$ & $0.069^{* * *}$ & $-0.038^{* *}$ \\
\hline & Sequentially remove one country & $\begin{array}{l}0.038^{* *} \text { to } \\
0.093^{* * *}\end{array}$ & $\begin{array}{l}-0.019 \text { to }- \\
0.056^{* * *}\end{array}$ \\
\hline \multicolumn{4}{|c|}{ Alternative estimation technique } \\
\hline & First Difference & $0.030^{* * *}$ & -0.004 \\
\hline
\end{tabular}

Note: Regressions are estimated by the fixed-effects estimator on an unbalanced panel. Robust standard errors are shown in parentheses and are clustered at the firm level. Significance levels are given by: ${ }^{*} \mathrm{p}<0.1,{ }^{* *} \mathrm{p}<0.05$ and $* * * \mathrm{p}<0.01$. All regressions include country-year and sector-year fixed effects (NACE4).

Source: Authors. 


\subsection{Extensions}

59. In this section, the heterogeneity of the impact is explored across sectors (section 4.4.1) and firm size in terms of number of employees (section 4.4.2).

\subsubsection{Effect by sector}

60. The large size of the firm-level dataset allows for analysing heterogeneous effects across sectors at a much finer level of granularity than with the sector-level dataset used in Section 3. At the broad sector level, the dataset includes between 3000 firms in non-ferrous metals and 94000 firms in machinery, representing between 500000 and 11 million employees (see Table 7).

Table 7. Summary statistics

\begin{tabular}{|c|c|c|c|c|c|c|c|c|}
\hline Sector & $\begin{array}{l}\text { Number of } \\
\text { firms }\end{array}$ & $\begin{array}{l}\text { Number of } \\
\text { observations }\end{array}$ & $\begin{array}{c}\text { Total } \\
\text { employees }\end{array}$ & $\begin{array}{c}\text { Median } \\
\text { number of } \\
\text { employees }\end{array}$ & $\begin{array}{l}\text { Log (energy } \\
\text { price index) }\end{array}$ & $\begin{array}{l}\text { Log } \\
\text { (hourly } \\
\text { wage) }\end{array}$ & Log (capital) & $\begin{array}{l}\text { Log (value } \\
\text { added per } \\
\text { worker) }\end{array}$ \\
\hline $\begin{array}{l}\text { Chemical and } \\
\text { petrochemical }\end{array}$ & 37445 & 237009 & 6499957 & 20 & 6.55 & 4.19 & 13.69 & 10.68 \\
\hline Food and tobacco & 54948 & 322341 & 5947033 & 10 & 6.51 & 3.26 & 12.92 & 10.41 \\
\hline Iron and steel & 67906 & 374343 & 4173559 & 13 & 6.23 & 4.06 & 12.60 & 10.55 \\
\hline Machinery & 94682 & 552524 & 11141378 & 13 & 6.63 & 4.37 & 12.55 & 10.58 \\
\hline Other manufacturing & 16857 & 95351 & 1320369 & 9 & 6.43 & 3.34 & 12.09 & 10.48 \\
\hline Non-ferrous metals & 3138 & 19573 & 532872 & 27 & 6.61 & 4.72 & 13.95 & 10.61 \\
\hline Non-metallic minerals & 23003 & 142496 & 2118637 & 12 & 6.22 & 3.54 & 13.05 & 10.46 \\
\hline Paper, pulp and print & 30764 & 184570 & 2072702 & 9 & 6.62 & 3.39 & 12.37 & 10.45 \\
\hline Textile and leather & 46436 & 255508 & 2565670 & 12 & 6.62 & 2.97 & 12.00 & 10.16 \\
\hline Transport equipment & 14386 & 86659 & 6988202 & 30 & 6.57 & 5.11 & 13.76 & 10.40 \\
\hline \multirow[t]{2}{*}{$\begin{array}{l}\text { Wood and wood } \\
\text { products }\end{array}$} & 41423 & 240039 & 1190339 & 8 & 6.71 & 3.07 & 11.93 & 10.20 \\
\hline & 430988 & 2510413 & 44550717 & & & & & \\
\hline
\end{tabular}

Source: Authors based on ORBIS, (Sato et al., 2019[24]).

61. Average energy prices differ substantially across sectors, depending on the geographical location of firms and the average fuel mix that they use. The lowest energy prices are found in energy-intensive sectors such as non-metallic minerals and iron and steel, consistent with these sectors resorting to cheaper sources of energy. Finally, there is ample variation in average hourly wages across sectors with more capital-intensive sectors paying higher average wages.

62. The effect of higher energy prices varies widely across sectors and sub-sectors. Figure 5 shows the average effect for each NACE 2-digit sector (red crosses) as well as the effect of all NACE 3-digit sub-sectors within each sector (shown as circles). Note that we still observe on average more than 4000 firms in each of the 114 NACE 3-digit sectors, so that most of the coefficients obtained are statistically significant. The energy price coefficient is as high as 0.76 (Manufacture of magnetic and optical media within Electrical equipment) and as low as -0.63 (Manufacture of refractory products within non-metallic minerals). This clearly shows that the average effect even on the NACE 2-digit level conceals vast heterogeneity at the sub-sector level. However, without knowing the economic structure and technical substitution possibilities across product groups, we can only speculate about labour substitution across sectors. 
Figure 5. Effect of energy price on employment by NACE 2-digit

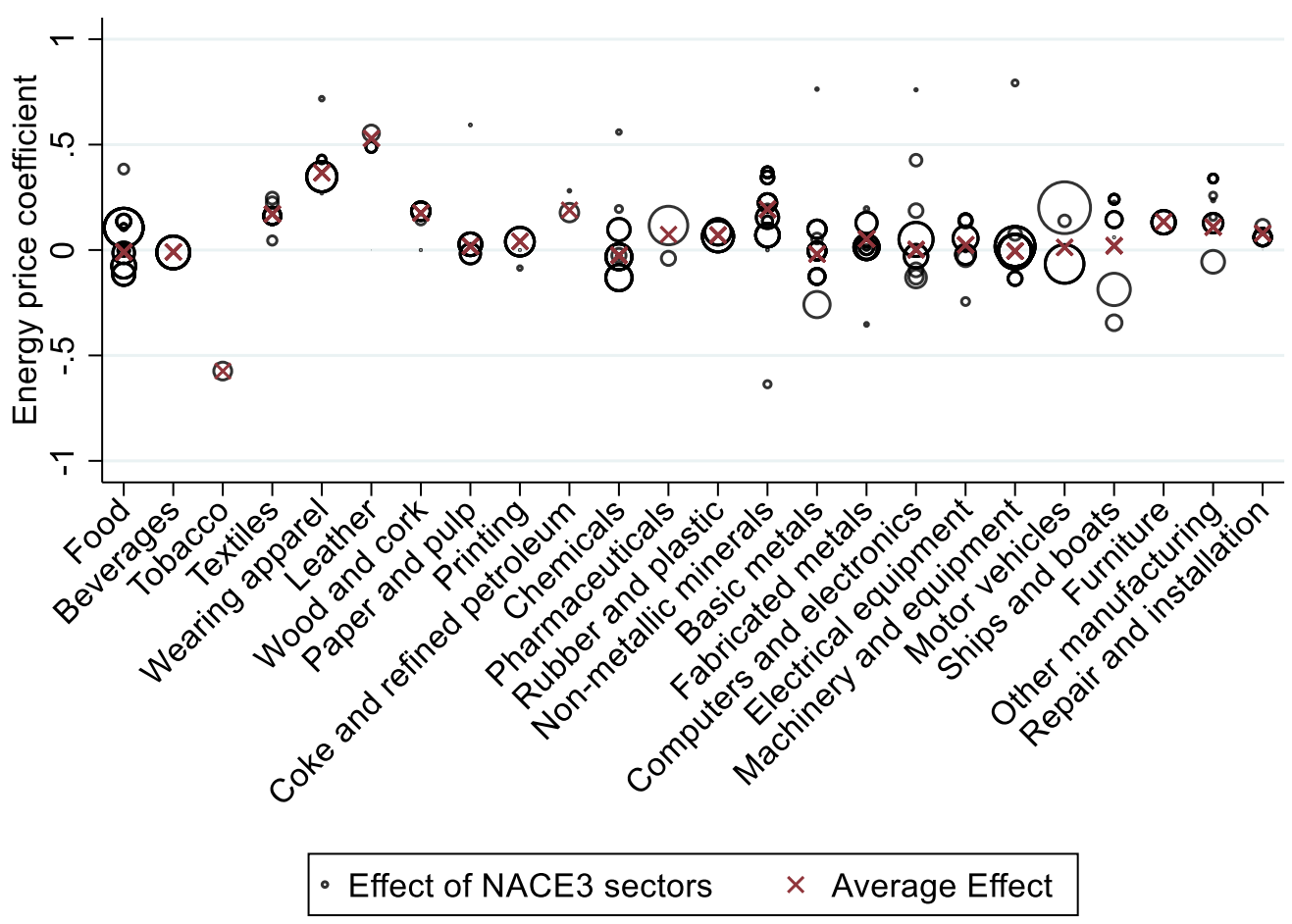

Note: The size of the bubbles reflects the aggregate employment in the respective NACE3 sector.

Source: Authors.

63. The effect of energy prices on employment varies even more for more fine-grained sectoral definitions. Figure 6 shows the average energy price coefficient at the NACE 3-digit level and the coefficients at the NACE 4-digit level in the three most energy-intense sectors (Chemicals and petrochemicals, non-metallic minerals, basic metals). The average effect on the NACE 3-digit level also here conceals heterogeneity across sub-sectors. For example, the average effect in the non-ferrous metals sector is -0.004 . However, within this sector, the effect can be as high as 0.563 (processing of nuclear fuel, an alternative to fossil fuel) and as low as -0.207 (lead, zinc and tin production).

64. A more fine-grained sectoral decomposition reveals that economic sectors are very differently affected by increasing energy prices. While firm-level employment in many sectors increases in response to higher energy prices, employment in other sectors decreases. The variation tends to increase with the granularity. Linked employer-employee data would enable drawing conclusions on the between-sector substitution of labour. 
Figure 6. Heterogeneous effects in the most energy intensive sectors

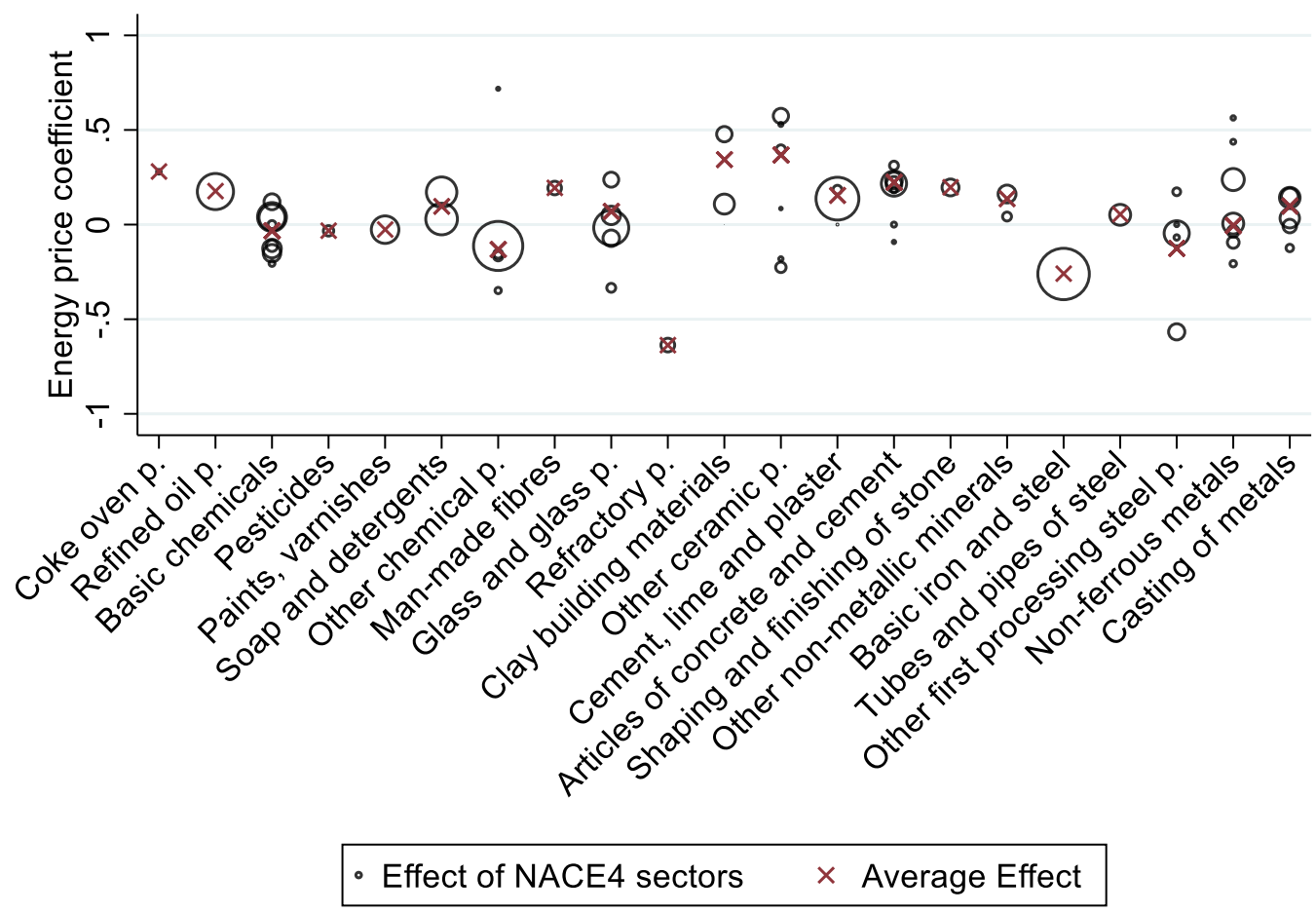

Note: The size of the bubbles reflects the aggregate employment in the respective NACE3 sector. The "p." is the abbreviation for products.

Source: Authors.

\subsubsection{Effect by firm size}

65. Firms of different size may be affected differently by changes in energy prices and environmental stringency. For example, smaller firms may lack the financial and human resources to invest in advanced production technologies. To shed more light on this issue, Table 8 shows the effect of increasing energy prices for different firm size groups, following the definition of the European Union: Micro companies ( $<10$ employees), small companies (10-50), medium $(51-250)$ and large $(>250)$ companies.

Table 8. Effect of energy prices and EPS depending on the number of employees

\begin{tabular}{|c|c|c|c|c|}
\hline Dep. variable: Log of employment (t) & Micro $(<10)$ & Small $(10-50)$ & Medium (51 - 250) & Large $(>250)$ \\
\hline \multirow[t]{2}{*}{ Log energy price (t-1) } & 0.023 & $0.082^{\star * \star}$ & $0.065^{* * *}$ & $0.055^{\star \star \star}$ \\
\hline & $(0.016)$ & $(0.016)$ & $(0.017)$ & $(0.020)$ \\
\hline \multirow[t]{2}{*}{ Log EPS (t-1) } & -0.012 & $-0.044^{* * *}$ & $-0.034^{* *}$ & $-0.062^{\star \star *}$ \\
\hline & $(0.016)$ & $(0.015)$ & $(0.016)$ & $(0.019)$ \\
\hline Country-year fixed effects & \multicolumn{4}{|c|}{ Yes } \\
\hline Sector-year fixed effects (NACE4) & \multicolumn{4}{|c|}{ Yes } \\
\hline \# Observations & \multicolumn{4}{|c|}{2510413} \\
\hline \# Firms & \multicolumn{4}{|c|}{430988} \\
\hline
\end{tabular}

Note: Regressions are estimated by the fixed-effects estimator on an unbalanced panel. Robust standard errors are shown in parentheses and are clustered at the firm level. Significance levels are given by: ${ }^{*} \mathrm{p}<0.1,{ }^{* *} \mathrm{p}<0.05$ and $* * * p<0.01$. All regressions include country-year and sector-year fixed effects (NACE4).

Source: Authors. 
66. Table 8 shows that firms with more than 10 employees increase their employment levels in response to higher energy prices. All three groups have a positive and statistically significant energy price coefficient. Table 8 also shows that higher environmental stringency tends to reduce firm-level employment for larger firms.

\section{Impact of energy price and environmental policy stringency on entry and exit}

67. At the sector level (Section 3) as at the firm level (Section 4), the impact of stricter environmental policy stringency on employment appears negative. But how can one reconcile the positive effect of energy prices on firm-level employment with the negative impact on total employment at the sector-level? A potential channel to reconcile these two contrasting results is through firm dynamics, i.e. the effect of energy prices and EPS on firm entry and exit.

\subsection{Data and methodology}

68. Data on the number of firm entries and exits at the country-sector level comes from the OECD-Eurostat Business Demography Statistics (OECD, 2019[32]). This database is based on information from national business registries. It covers 15 manufacturing sectors in 34 countries from 2007 to 2017. Moreover, it also distinguishes entry and exit of firms by firm size in terms of number of employees. ${ }^{12}$

69. To estimate the impact of energy prices and environmental policy stringency on entry and exit, we broadly follow the methodology outlined in Section 3. (see equation 1), with some small differences. First, the time period covered by the Business Demography Statistics database is much shorter. To keep the number of observations as large as possible and increase precision, the effect of energy prices and EPS are estimated in separate regressions. ${ }^{13}$ Second, the dependent variables are count variables and include zeros so fixed effects Poisson regressions are used instead of OLS. The inclusion of country and sector quadratic trends prevented maximum likelihood estimation to converge, so linear (rather than quadratic) country and sector trends are used instead, in conjunction with additional country-level control variables (GDP and public expenditure on labour market).

\subsection{Results}

70. The results clearly show that higher energy prices accelerate firm exit (Table 9): A $10 \%$ increase in energy prices leads to a $7.5 \%$ increase in the number of firms exiting the market. The estimated coefficient implies that a $10 \%$ increase in energy prices would lead to an additional exit of 510 firms across OECD countries. This effect is even more pronounced for larger firms (i.e. firms with more than 10 employees) with a coefficient of 1.74 (see column 2). The vast majority of firms exiting the market are firms with less than 10 employees, explaining why the coefficient for total exit is close in magnitude to that for exit of small firms. There is no evidence that higher energy prices would reduce or trigger firm entry (last column Table 9).

12. 1-4 employees; 5-9 employees; $>9$ employees; $>19$ employees (in few countries).

13. Focusing on the intersection of the energy price and EPS data reduces the sample size by about a third. 
Table 9. Impacts of energy price and EPS on firm exit and entry

\begin{tabular}{rcccc}
\hline Dep. variable: Number of firms $(\mathrm{t})$ & Total exit & Exit $=>10$ & Exit $<10$ & Entry \\
\hline Log energy price $(\mathrm{t}-1)$ & $0.749^{* \star}$ & $1.738^{* * *}$ & $0.719^{* \star}$ & -0.156 \\
& $(0.350)$ & $(0.368)$ & $(0.355)$ & $(0.146)$ \\
Log EPS $(\mathrm{t}-1)$ & -0.394 & 0.316 & -0.351 & -0.165 \\
& $(0.241)$ & $(0.280)$ & $(0.244)$ & $(0.104)$ \\
\hline Country-sector linear trends & Yes & Yes & Yes & Yes \\
Year fixed effects & Yes & Yes & Yes & Yes \\
\hline \# Observations energy price & 3123 & 2695 & 3090 & 3123 \\
\# Observations EPS & 2348 & 2049 & 2315 & 2453 \\
\hline
\end{tabular}

Note: Regressions are estimated by the fixed-effects estimator on an unbalanced panel using Poisson regressions. Robust standard errors are shown in parentheses and are clustered at the sector-country level. Significance levels are given by: $* \mathrm{p}<0.1, * * \mathrm{p}<0.05$ and $* * * \mathrm{p}<0.01$. All regressions include linear countrysector trends.

Source: Authors.

71. Accelerated firm exit due to higher energy prices can be the missing link to reconcile the results of a positive effect of energy prices on the employment of surviving firms with the negative impact on total employment at the sector-level. As higher energy prices trigger firm exit, surviving firms can expand, potentially explaining the positive coefficient at the firm level. Indeed, accelerated firm exit should result in higher market shares and, hence, higher turnover for surviving firms. In fact, there is evidence that surviving firms increase their gross output in response to higher energy prices. A $10 \%$ increase in energy prices leads to an increase of gross output of $0.64 \%$, and this effect is statistically significant at the $1 \%$ level (Table A.3). In addition, the larger coefficient for firm exit of larger firms is also in line with the results reported in Table 8, which shows that the positive effect of higher energy prices on firm-level employment is larger for larger firms. As higher energy prices tend to accelerate firm exit of larger firms relatively more, if large firms tend to compete with each other, then larger surviving firms will increase their market share, output and, thus, employment.

72. There is some heterogeneity in the impact of energy prices on exit across sectors, but the smaller size of the sample leads to larger and thus overlapping confidence intervals.

73. There is no evidence for an effect of higher environmental stringency on both firm exit and entry (second row Table 9). As environmental stringency does not tend to affect firm dynamics, the negative effect of more stringent environmental regulation on surviving firms seems to be the main channel for the negative employment effect on the sector-level. One explanation for the different effects of energy prices and EPS on entry and exit could be related to vintage differentiation, whereby less stringent environmental regulations typically apply to incumbents, which convey some monopoly power. This could counteract the potentially negative impact of EPS on exit. Indeed, separating the EPS into its marketbased and non-market based components, we find that an increase in the stringency of market-based environmental policies discourages firm entry. A possible explanation for reduced entry could be that some market-based policies such as carbon markets tend to treat incumbents more favourably, for example by allocating free allocations through grandfathering. This can discourage new firms from entering the market while shielding existing firms from more competition.

74. The results concerning the effect of energy prices on exit were subjected to a number of robustness tests (Table 10 in Box 3). The point estimate for the energy price effect on firm exit is positive in all but one specifications. While being statistically 
significant in most cases, the point estimates become smaller and not statistically significant in highly demanding specifications (e.g. when country trends are replaced by country-year fixed effects). For the sake of brevity, robustness tests for non-significant results in Table 9 are not reported below. However, running the same checks as in Box 3 for the effect of energy prices on entry and for the effect of EPS on exit and entry yields non-significant coefficients in virtually all cases.

\section{Box 3. Robustness checks for firm exit}

The same robustness checks as for the analysis of sector-level employment have been carried out to test the sensitivity of the effect of energy prices on firm exit with the exception of the first-difference estimator which is incompatible with a Poisson regression. Details on the nature of the robustness checks are available in Box 1.

In general, the results are robust to these tests and as before, the coefficient becomes insignificant when including country-year fixed effects, but this time the coefficient goes down significantly, suggesting our baseline results might overestimate the true effect on firm exit.

Table 10. Robustness tests for the effect of energy price on firm exit

\begin{tabular}{|c|c|c|c|c|}
\hline Dimension & Robustness check & \multicolumn{3}{|c|}{ Dependent variable } \\
\hline \multirow[t]{4}{*}{ Control variables } & & Total exit & Exit $=>10$ & Exit $<10$ \\
\hline & No sector-level control variables & $0.767^{\star *}$ & $1.818^{\star \star *}$ & $0.739^{* *}$ \\
\hline & Adding country-level controls & $0.625^{*}$ & $2.024^{\star \star *}$ & $0.622^{\star *}$ \\
\hline & Substituting real wage by unit labour cost & $0.755^{\star \star}$ & $1.723^{\star \star \star}$ & $0.727^{\star \star}$ \\
\hline \multicolumn{5}{|c|}{ Country and sector controls } \\
\hline & No time trend & 0.017 & $1.759^{* * *}$ & 0.036 \\
\hline & Sector-year fixed effects & $0.716^{* *}$ & $1.531^{* * *}$ & $0.681^{* *}$ \\
\hline & Country-year fixed effects & 0.219 & 0.291 & 0.219 \\
\hline & Sector-year and country-year FE & 0.053 & -0.363 & 0.036 \\
\hline \multicolumn{5}{|l|}{ Lag structure } \\
\hline & No lag & $1.981^{* * *}$ & $3.847^{\star \star *}$ & $1.935^{\star * *}$ \\
\hline & $\operatorname{Lag} 1+\operatorname{Lag} 2$ & $1.264^{* * *}$ & $1.658^{\star \star *}$ & $1.282^{* * *}$ \\
\hline \multicolumn{5}{|c|}{$\begin{array}{l}\text { Alternative explanatory } \\
\text { variables }\end{array}$} \\
\hline & Different base years of cons. shares & $\begin{array}{l}0.739^{* *} \text { to } \\
0.852^{* *}\end{array}$ & $\begin{array}{l}1.446^{* \star *} \text { to } \\
1.865^{\star * *}\end{array}$ & $\begin{array}{l}0.712^{* *} \text { to } \\
0.823^{* *}\end{array}$ \\
\hline & VEPL & $1.013^{* * *}$ & $1.861^{\star * \star}$ & $0.979^{* * *}$ \\
\hline \multicolumn{5}{|l|}{ Outliers } \\
\hline & Remove largest $1 \%$ of entries and exits & $0.746^{* *}$ & $1.625^{\star * *}$ & $0.725^{\star *}$ \\
\hline
\end{tabular}

Note: Regressions are estimated by the fixed-effects estimator on an unbalanced panel using Poisson regressions. Robust standard errors are shown in parentheses and are clustered at the sector-country level. Significance levels are given by: ${ }^{*} \mathrm{p}<0.1,{ }^{* *} \mathrm{p}<0.05$ and $* * * \mathrm{p}<0.01$.

Source: Authors. 


\section{Conclusion}

75. This paper investigates the impacts of environmental policy (measured by energy prices and the Environmental Policy Stringency indicator) on employment both at the sector and at the firm level across OECD countries over the period 2000 to 2014. The results show that, at the sector level, increases in energy prices and in the stringency of environmental policies have a small but negative and statistically significant impact on total employment, with the most energy-intensive sectors affected the most. Even in highly energy-intensive sectors, however, the size of the effects is relatively small. At the firm level, however, the results show that higher energy prices have a statistically significant and small positive effect on the employment level of surviving firms. The opposing effects of higher energy prices at the sector-level and firm-level can be reconciled when looking at business dynamics. The analysis on energy price's effect on firm exit and entry shows that higher energy prices increase the probability of firm exit. Accelerated firm exit allows surviving firms to expand, boosting firm-level employment. Contrary to higher energy prices, stricter environmental policies reduce employment of surviving firms in line with the sector-level analysis. Looking at business dynamics, stricter environmental policies do not significantly affect entry or exit of firms.

76. The analysis has two main limitations. First, to the extent that changes in energy prices or environmental regulations induce a rapid shift in demand (and thus employment) from strictly to less-strictly regulated sectors and regions, estimates of employment losses presented here would be biased upward. The extent of such general equilibrium effects are difficult to estimate, but the results should be understood as an upper-bound of the true effect of higher energy prices and stricter environmental policies. Second, the results are only valid in the short run. In the longer run, there might be no net effect on job losses as workers move from contracting or exiting firms to other firms or other sectors (in particular, the analysis focuses on the manufacturing sector, but affected workers might find jobs in the services sector).

77. However, the analysis clearly demonstrates that there exist transition costs in the short run to imposing stricter environmental policies, as some workers are forced to move away from affected firms and sectors, even if many of these job losses are unlikely to be permanent as laid-off workers may ultimately find other jobs. Because these reallocation effects have redistributive implications and generate costs for laid-off workers, these results call for complementary labour market policies that minimize those costs on affected workers and ease between-firms adjustments in employment. Moreover, since these transition costs are typically highly localised in regions specialised in polluting activities, they can also translate into potentially significant regional effects and thus political costs.

78. Future work could follow different avenues, including:

- A more detailed analysis of environmental policy packages (e.g. investigating the effect of combinations of environmental policies and of environmental policies combined with non-environmental policies such as labour market policies);

- A more fine-grained analysis on the employment dimension beyond the number of employees (e.g. breaking down employment into permanent and temporary workers; differential effects on different skill types, including unskilled, skilled and highly skilled; and analysing the impact on wages);

- Analysing the heterogeneity of the response to higher energy prices and stricter environmental policies across regions by adding information on the geographical 
location of firms, and, distinguishing for example between urban and rural regions or examining impacts across the income distribution according to the average income of the region;

- Taking into account the political economy dimension, in order to help design socially-acceptable environmental policies;

- Finally, the effect of environmental policy on other outcome variables is worth further investigation (e.g. market concentration; value added of sectors and firms; offshoring, pollution haven effects and carbon leakage). 


\section{Annex A.}

Figure A.1. Correlation between residuals from regressions of energy prices and EPS on country and year dummies

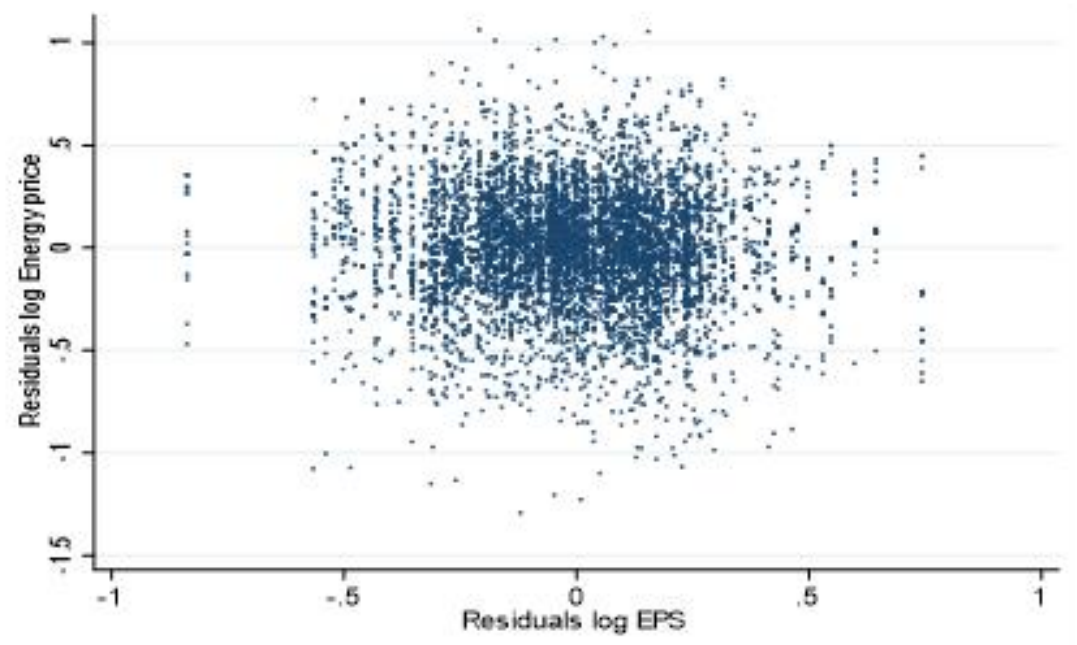

Note: This graph shows the residuals of regressions, in which EPS and energy prices are regressed on year and country dummy variables. After controlling for these two factors, there is apparently no relationship between EPS and energy prices.

Source: Authors.

Figure A.2. Sector-level analysis: Effect of EPS on employment by sector

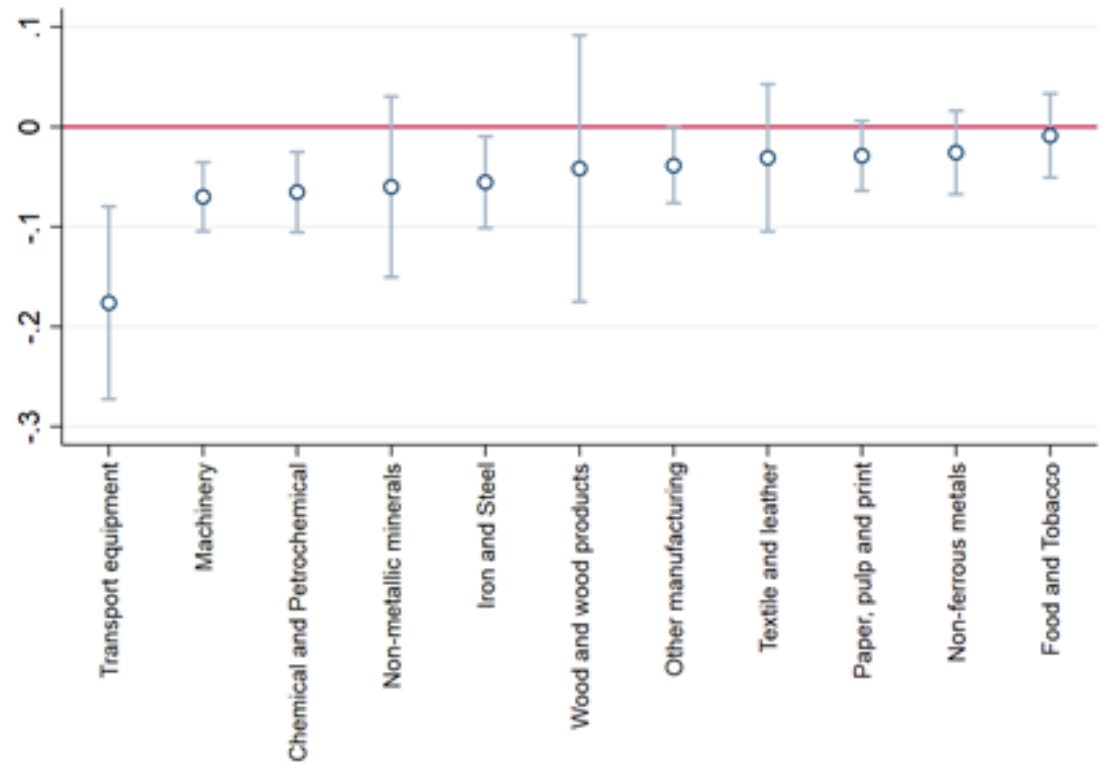

Source: Authors. 
Figure A.3. Firm-level analysis: Variation of energy prices

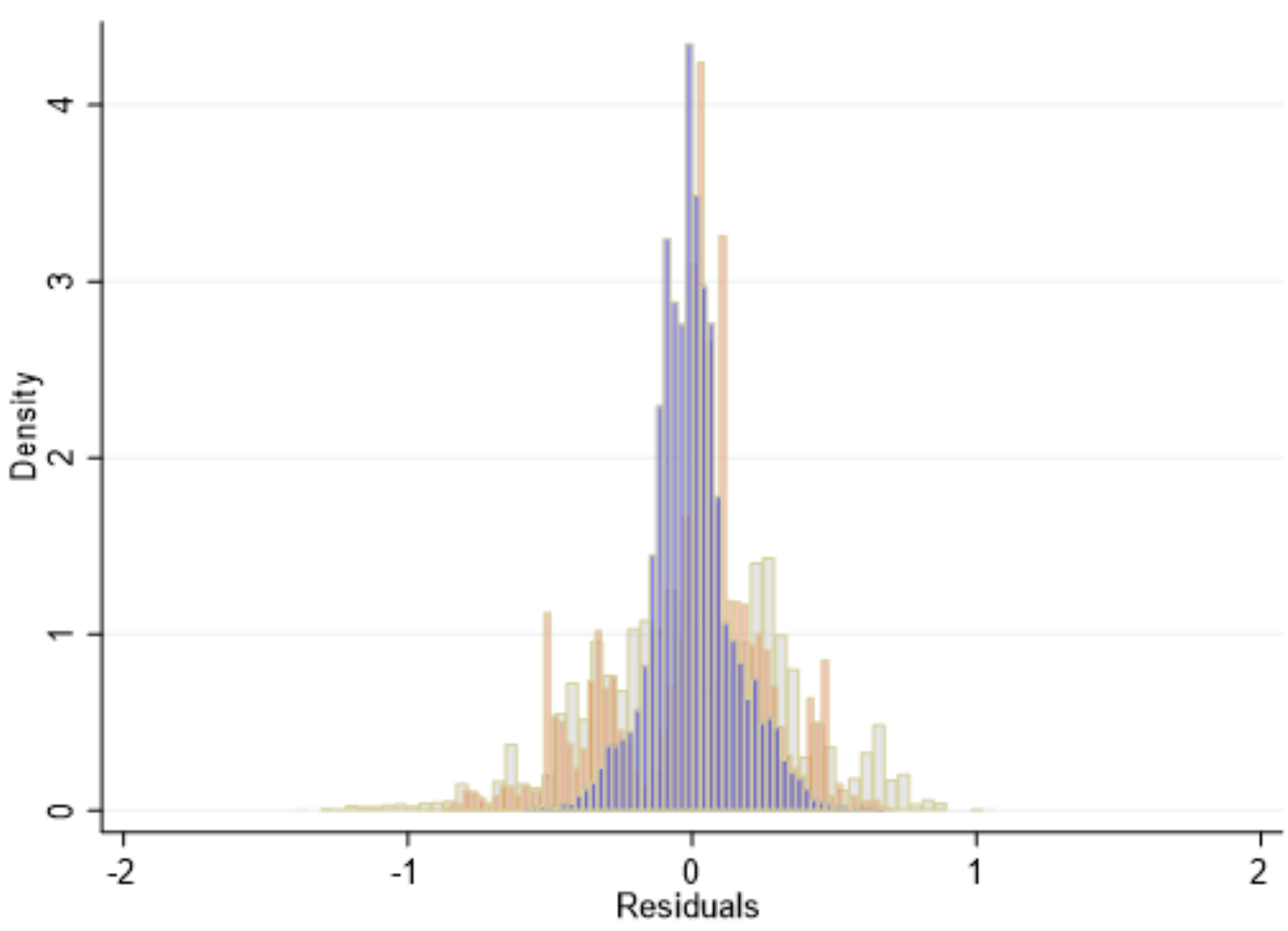

Note: The grey bars show the remaining variation of energy prices after regressing them on year fixed effects, the orange bars show the variation after regressing on country-year fixed effects, blue bars show the variation after regressing on country-year and sector-year fixed effects.

Source: Authors.

Table A.1. Effect of market and non-market-based EPS on employment

\begin{tabular}{|c|c|c|c|c|c|c|c|c|}
\hline & (1) & (2) & (3) & (4) & (5) & (6) & (7) & (8) \\
\hline \multirow[t]{2}{*}{ Log energy price $(t-1)$} & $-0.070^{* *}$ & $-0.072^{\star *}$ & $-0.063^{* *}$ & $-0.092^{\star * \star}$ & & & & \\
\hline & $(0.032)$ & $(0.032)$ & $(0.031)$ & $(0.033)$ & & & & \\
\hline \multirow[t]{2}{*}{ Log EPS (t - 1) } & $-0.058^{\star * *}$ & & & & $-0.049^{* * *}$ & & & \\
\hline & $(0.015)$ & & & & $(0.014)$ & & & \\
\hline \multirow[t]{2}{*}{ Log Market-based EPS ( $\mathrm{t}$ - 1) } & & $-0.013^{* *}$ & & $-0.015^{\star \star}$ & & -0.008 & & -0.008 \\
\hline & & $(0.006)$ & & $(0.006)$ & & $(0.005)$ & & $(0.005)$ \\
\hline \multirow[t]{2}{*}{ Log Non Market-based EPS ( $\mathrm{t}$ - 1) } & & & $-0.044^{\star \star \star}$ & $-0.049^{* * *}$ & & & $-0.039^{\star * *}$ & $-0.043^{* * *}$ \\
\hline & & & $(0.012)$ & $(0.012)$ & & & $(0.011)$ & $(0.011)$ \\
\hline \# Observations & 6494 & 6361 & 6622 & 6622 & 6566 & 6433 & 6718 & 6622 \\
\hline \# Country-sectors & 518 & 518 & 518 & 518 & 526 & 526 & 526 & 518 \\
\hline
\end{tabular}

Note: Regressions are estimated by the fixed-effects estimator on an unbalanced panel. Robust standard errors are shown in parentheses and are clustered at the sector-country level. Significance levels are given by: ${ }^{*} p<0.1$, $* * \mathrm{p}<0.05$ and $* * * \mathrm{p}<0.01$. All regressions include linear and quadratic country and sector trends and the control variables as shown in equation (1).

Source: Authors. 
Table A.2. Coverage of firms in ORBIS by country

\begin{tabular}{|c|c|c|c|}
\hline Country & Number of firms in ORBIS & Share of ORBIS sample & Share of all firms \\
\hline AUS & 27 & $0.01 \%$ & $0.02 \%$ \\
\hline AUT & 65 & $0.03 \%$ & $0.25 \%$ \\
\hline BEL & 3475 & $1.62 \%$ & $10.05 \%$ \\
\hline CZE & 8 & $0.00 \%$ & $0.01 \%$ \\
\hline DEU & 4552 & $2.12 \%$ & $2.27 \%$ \\
\hline DNK & 779 & $0.36 \%$ & $4.75 \%$ \\
\hline ESP & 51335 & $23.93 \%$ & $25.73 \%$ \\
\hline FIN & 4511 & $2.10 \%$ & $19.68 \%$ \\
\hline FRA & 23143 & $10.79 \%$ & $10.46 \%$ \\
\hline GBR & 7890 & $3.68 \%$ & $6.27 \%$ \\
\hline GRC & 26 & $0.01 \%$ & $0.03 \%$ \\
\hline HUN & 4928 & $2.30 \%$ & $9.00 \%$ \\
\hline IRL & 215 & $0.10 \%$ & $2.06 \%$ \\
\hline ITA & 57209 & $26.67 \%$ & $13.00 \%$ \\
\hline JPN & 12 & $0.01 \%$ & NA \\
\hline KOR & 18480 & $8.62 \%$ & NA \\
\hline NLD & 260 & $0.12 \%$ & $0.56 \%$ \\
\hline POL & 7 & $0.00 \%$ & $0.00 \%$ \\
\hline PRT & 20259 & $9.44 \%$ & $26.00 \%$ \\
\hline SVN & 3937 & $1.84 \%$ & $22.99 \%$ \\
\hline SWE & 13212 & $6.16 \%$ & $24.28 \%$ \\
\hline TUR & 54 & $0.03 \%$ & $0.02 \%$ \\
\hline USA & 121 & $0.06 \%$ & $0.03 \%$ \\
\hline
\end{tabular}

Note: The table is based on firms in the final sample. Number of firms refers to the average number of firms across years where firm-level data are available. Share of all firms is based on the average number of firms from OECD's Structural Business Statistics Database. No data for KOR and JPN are available in this database. Source: Authors based on ORBIS and (OECD, 2019[33]).

Table A.3. Effect of energy prices and EPS on gross output

\begin{tabular}{|c|c|c|c|}
\hline Dep. variable: Log of gross output (t) & (1) & (2) & (3) \\
\hline Log energy price $(t-1)$ & $0.064^{* * *}$ & $0.053^{* * *}$ & \\
\hline & $(0.017)$ & $(0.017)$ & \\
\hline $\log$ EPS $(t-1)$ & $-0.047^{\star * *}$ & & $-0.039^{* *}$ \\
\hline & $(0.016)$ & & $(0.016)$ \\
\hline Log hourly wage (t - 1) & $-0.065^{\star \star *}$ & $-0.064^{\star \star *}$ & $-0.067^{* * *}$ \\
\hline & $(0.008)$ & $(0.008)$ & $(0.008)$ \\
\hline Log capital (t - 1) & $0.124^{* \star *}$ & $0.124^{\star * *}$ & $0.124^{* * *}$ \\
\hline & $(0.001)$ & $(0.001)$ & $(0.001)$ \\
\hline Log value added per worker ( $t$ - 1) & $0.135^{\star \star *}$ & $0.135^{\star \star \star}$ & $0.135^{\star * *}$ \\
\hline & $(0.001)$ & $(0.001)$ & $(0.001)$ \\
\hline Country-year fixed effects & Yes & Yes & Yes \\
\hline Sector-year fixed effects (NACE4) & Yes & Yes & Yes \\
\hline \# Observations & 2497578 & 2497578 & 2497578 \\
\hline \# Firms & 429150 & 429150 & 429150 \\
\hline
\end{tabular}

Note: Standard errors are shown in parentheses and are clustered on firm level. Significance levels are given by: ${ }^{*} \mathrm{p}<0.1,{ }^{* *} \mathrm{p}<0.05$ and ${ }^{* * *} \mathrm{p}<0.01$. 


\section{References}

Abowd, J., R. Creecy and F. Kramarz (2002), "Longitudinal Employer-Household Dynamics Computing Person and Firm Effects Using Linked Longitudinal Employer-Employee Data", Longitudinal Employer-Household Dynamics Technical Papers, Center for Economic Studies, U.S. Census Bureau.

Acemoglu, D. and P. Restrepo (2017), Robots and Jobs: Evidence from US Labor Markets, National Bureau of Economic Research, Cambridge, MA, http://dx.doi.org/10.3386/w23285.

Aldy, J. and W. Pizer (2015), "The Competitiveness Impacts of Climate Change Mitigation Policies", Journal of the Association of Environmental and Resource Economists, Vol. 2/4, pp. 565-595, http://www.nber.org/papers/w17705.

Anger, N. and U. Oberndorfer (2008), "Firm performance and employment in the EU emissions trading scheme: An empirical assessment for Germany", Energy Policy, Vol. 36/1, pp. 12-22, http://dx.doi.org/10.1016/j.enpol.2007.09.007.

Bajgar, M. et al. (2020), "Coverage and representativeness of Orbis data", OECD Science, Technology and Industry Working Papers, No. 2020/06, OECD Publishing, Paris, https://dx.doi.org/10.1787/c7bdaa03-en.

Bajgar, M. et al. (Forthcoming), "To Use or Not to Use (and How to Use): Coverage and Representativeness of Orbis Data", OECD STI Working Paper.

Bartik, T. (2013), Social Costs of Jobs Lost Due to Environmental Regulations, WE Upjohn Institute for Employment Research.

Belova, A. et al. (2013), "Environmental Regulation and Industry Employment: A Reassessment”, US Census Bureau Center for Economic Studies Paper No. CES-WP-13-36.

Berman, E. and L. Bui (2001), "Environmental regulation and labor demand: evidence from the South Coast Air Basin", Journal of Public Economics, Vol. 79/2, pp. 265-295, http://dx.doi.org/10.1016/s0047-2727(99)00101-2.

Botta, E. and T. Koźluk (2014), "Measuring Environmental Policy Stringency in OECD Countries: A Composite Index Approach", OECD Economics Department Working Papers, No. 1177, OECD Publishing, Paris, https://dx.doi.org/10.1787/5jxrjnc45gvg-en.

Caliendo, L., M. Dvorkin and F. Parro (2019), "Trade and Labor Market Dynamics: General Equilibrium Analysis of the China Trade Shock", Econometrica, Vol. 87/3, pp. 741-835, http://dx.doi.org/10.3982/ecta13758.

Cole, M. and R. Elliott (2007), "Do environmental regulations cost jobs? An industry-level analysis of the UK", The BE Journal of Economic Analysis \& Policy, Vol. 7/1. 
de Serres, A., F. Murtin and G. Nicoletti (2010), “A Framework for Assessing Green Growth Policies", OECD Economics Department Working Papers, No. 774, OECD Publishing, Paris, https://dx.doi.org/10.1787/5kmfj2xvemkf-en.

Dechezleprêtre, A. et al. (2019), "Do Environmental and Economic Performance Go Together? A Review of Micro-level Empirical Evidence from the Past Decade or So", International Review of Environmental and Resource Economics, Vol. 13/1-2, pp. 1-118, http://dx.doi.org/10.1561/101.00000106.

Dechezleprêtre, A., D. Nachtigall and F. Venmans (2018), "The joint impact of the European Union emissions trading system on carbon emissions and economic performance", $O E C D$ Economics Department Working Papers, No. 1515, OECD Publishing, Paris, https://dx.doi.org/10.1787/4819b016-en.

Deschenes, O. (2018), "Environmental regulations and labor markets", IZA World of Labor, http://dx.doi.org/10.15185/izawol.22.v2.

Deschenes, O. (2011), "Climate policy and labor markets", in Fullerton, D. and C. Wolfram (eds.), The design and implementation of US climate policy, University of Chicago Press, Chicago, http://www.nber.org/chapters/c12150.pdf (accessed on 25 January 2019).

Fankhäuser, S., F. Sehhleier and N. Stern (2008), "Climate change, innovation and jobs", Climate Policy, Vol. 8/4, pp. 421-429, http://dx.doi.org/10.3763/cpol.2008.0513.

Ferris, A., R. Shadbegian and A. Wolverton (2014), "The Effect of Environmental Regulation on Power Sector Employment: Phase I of the Title IV SO2 Trading Program", Journal of the Association of Environmental and Resource Economists, Vol. 1/4, pp. 521-553, http://dx.doi.org/10.1086/679301.

Garsous, G. and T. Kozluk (2017), "Foreign Direct Investment and The Pollution Haven Hypothesis: Evidence from Listed Firms", OECD Economics Department Working Papers, No. 1379, OECD Publishing, Paris, https://dx.doi.org/10.1787/1e8c0031-en.

Greenstone, M. (2001), The Impacts of Environmental Regulations on Industrial Activity: Evidence from the $1970 \& 1977$ Clean Air Act Amendments and the Census of Manufactures, National bureau of economic research.

Hafstead, M. and R. Williams (2019), Jobs and Environmental Regulation, National Bureau of Economic Research, Cambridge, MA, http://dx.doi.org/10.3386/w26093.

Hille, E. and P. Möbius (2019), "Do energy prices affect employment? Decomposed international evidence", Journal of Environmental Economics and Management, Vol. 96, pp. 1-21, http://dx.doi.org/10.1016/j.jeem.2019.04.002.

Kahn, M. and E. Mansur (2013), "Do local energy prices and regulation affect the geographic concentration of employment?", Journal of Public Economics, Vol. 101, pp. 105-114. 
Martin, R., M. Muûls and U. Wagner (2015), "The Impact of the European Union Emissions Trading Scheme on Regulated Firms: What Is the Evidence after Ten Years?", Review of Environmental Economics and Policy, Vol. 10/1, pp. 129-148, http://dx.doi.org/10.1093/reep/rev016.

Morgenstern, R., W. Pizer and J. Shih (2002), "Jobs versus the environment: an industry-level perspective", Journal of Environmental Economics and Management, Vol. 43/3, pp. 412-436.

OECD (2019), "Business demography indicators ISIC Rev. 4", Structural and Demographic Business Statistics (database), https://dx.doi.org/10.1787/9e2bb05a-en (accessed on 2 December 2019).

OECD (2019), "Environmental policy: Environmental Policy Stringency index", OECD Environment Statistics (database), https://dx.doi.org/10.1787/2bc0bb80-en (accessed on 2 December 2019).

OECD (2019), "Structural business statistics ISIC Rev. 4", Structural and Demographic Business Statistics (database), https://dx.doi.org/10.1787/8e34f7e 7-en (accessed on 18 December 2019).

Rajan, R. and L. Zingales (1998), "Financial Dependence and Growth", The American Economic Review, Vol. 88/3, pp. 559-586, http://dx.doi.org/10.2307/116849.

Sato, M. et al. (2019), "International and sectoral variation in industrial energy prices 19952015”, Energy Economics, Vol. 78, pp. 235-258, http://dx.doi.org/10.1016/j.eneco.2018.11.008.

Sato, M. et al. (2015), "International and sectoral variation in energy prices 1995-2011: how does it relate to emissions policy stringency?", Gratham Research Institute Working Papers, Vol. No. 187, https://econpapers.repec.org/paper/lsglsgwps/wp187.htm (accessed on 7 May 2018).

Walker, W. (2013), "The transitional costs of sectoral reallocation: evidence from the Clean Air Act and the workforce", The Quarterly Journal of Economics, Vol. 1787, p. 1835.

Walker, W. (2011), "Environmental regulation and labor reallocation: Evidence from the Clean Air Act", The American Economic Review, Vol. 101/3, pp. 442-447.

Yamazaki, A. (2017), "Jobs and climate policy: Evidence from British Columbia's revenueneutral carbon tax", Journal of Environmental Economics and Management, Vol. 83, pp. 197216, http://dx.doi.org/10.1016/j.jeem.2017.03.003. 